\title{
Polyphase evolution of Pelagonia (northern Greece) revealed by geological and fission-track data
}

\author{
F. L. Schenker ${ }^{1,2}$, M. G. Fellin ${ }^{1}$, and J.-P. Burg ${ }^{1}$ \\ ${ }^{1}$ Department of Earth Sciences, ETH Zurich, Sonneggstrasse 5, 8092 Zurich, Switzerland \\ ${ }^{2}$ Institute of Earth Sciences, University of Lausanne, 1015 Lausanne, Switzerland \\ Correspondence to: F. L. Schenker (filippo.schenker@unil.ch)
}

Received: 2 October 2014 - Published in Solid Earth Discuss.: 10 November 2014

Revised: 21 December 2014 - Accepted: 29 January 2015 - Published: 25 February 2015

\begin{abstract}
The Pelagonian zone, situated between the External Hellenides/Cyclades to the west and the Axios/Vardar/Almopias zone (AVAZ) and the Rhodope to the east, was involved in late Early Cretaceous and in Late Cretaceous-Eocene orogenic events whose duration and extent are still controversial. This paper constrains their late thermal imprints. New and previously published zircon (ZFT) and apatite (AFT) fission-track ages show cooling below $240^{\circ} \mathrm{C}$ of the metamorphic western AVAZ imbricates between 102 and 93-90 Ma, of northern Pelagonia between 86 and $68 \mathrm{Ma}$, of the eastern AVAZ at $80 \mathrm{Ma}$ and of the western Rhodope at $72 \mathrm{Ma}$. At the regional scale, this heterogeneous cooling is coeval with subsidence of Late Cretaceous marine basin(s) that unconformably covered the Early Cretaceous (130-110 Ma) thrust system from $100 \mathrm{Ma}$. Thrusting resumed at $70 \mathrm{Ma}$ in the AVAZ and migrated across Pelagonia to reach the External Hellenides at 40-38 Ma. Renewed thrusting in Pelagonia is attested at $68 \mathrm{Ma}$ by abrupt and rapid cooling below $240^{\circ} \mathrm{C}$ and erosion of the gneissic rocks. ZFT and AFT in western and eastern Pelagonia, respectively, testify at $\sim 40 \mathrm{Ma}$ to the latest thermal imprint related to thrusting. Central-eastern Pelagonia cooled rapidly and uniformly from 240 to $80^{\circ} \mathrm{C}$ between 24 and $16 \mathrm{Ma}$ in the footwall of a major extensional fault. Extension started even earlier, at $\sim 33 \mathrm{Ma}$ in the western AVAZ. Post-7 Ma rapid cooling is inferred from inverse modeling of AFT lengths. It occurred while E-W normal faults were cutting Pliocene-torecent sediment.
\end{abstract}

\section{Introduction}

The NW-SE trending Pelagonian zone in northern Greece (Fig. 1a, Schermer et al., 1990; Kilias et al., 2010; Schenker et al., 2014) is tectonically overlain by imbricates of a Late Triassic-Middle Jurassic passive margin (the Axios/Vardar/Almopias zone, AVAZ) to the northeast (e.g., Bernoulli and Laubscher, 1972). Pelagonia and the AVAZ are exposed between two composite nappe complexes with distinct orogenic histories (Figs. 1a and 2). To the northeast, the Rhodope collisional system was essentially built up between the Late Jurassic and the Early Cretaceous and reworked during the Eocene-Miocene extension (references in Burg, 2012). To the southwest, the fold-and-thrust belt of the External Hellenides formed during Eocene-to-Miocene times (e.g., Aubouin, 1973). The Pelagonian zone experienced two thrust events, one during the late Early Cretaceous and the next during the Eocene (Godfriaux et al., 1988; Schermer, 1993; Schenker et al., 2014) followed by Miocene extension (e.g., Schermer et al., 1990; Lecassin et al., 2007; Coutand et al., 2014). This history imprinted a complex distribution of low-temperature thermochronometric data, which comprise: zircon fission track (ZFT), zircon (U-Th) / He (ZHe), apatite fission track (AFT) and apatite (U-Th)/ He (AHe) (Most, 2003; Vamvaka et al., 2010; Coutand et al., 2014). To the north, ZFT ages range between 86 and $48 \mathrm{Ma}$ and AFT ages between 46 and $25 \mathrm{Ma}$ with the younger ages in the west. To the south, ZFT ages range between 76 and $32 \mathrm{Ma}$, ZHe between 53 and $20 \mathrm{Ma}$, AFT between 42 and $8 \mathrm{Ma}$ and AHe between 26 and $6 \mathrm{Ma}$ with the younger ages in the east (Fig. 1). Integrated into a geological and structural frame, these widely distributed low-temperature (from 240 to $70^{\circ} \mathrm{C}$; 

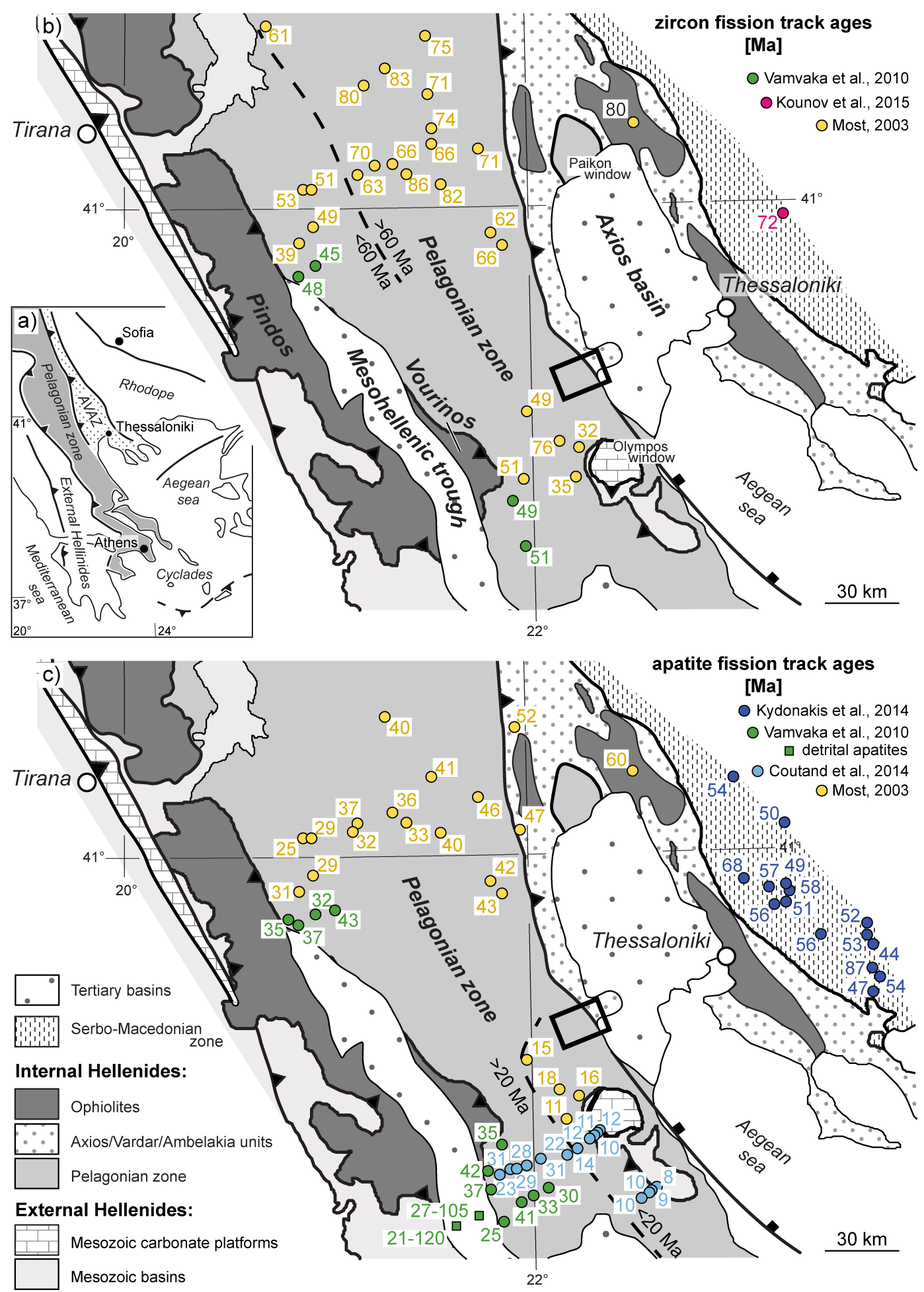

Figure 1. (a) Overview map (center left) and tectonic maps of the Hellenides (modified after Burg, 2012) with published ZFT ages (b) and AFT ages (c). Errors of the FT ages range between 1.6 and 11 Ma. Detrital AFT data are reported as the range of single-grain ages. In the southern Pelagonia, ZHe and AHe ages of Countand (2014) are similar to, respectively, ZFT and AFT age patterns. Working area shown in the bold inset. 
Reiners and Brandon, 2006) cooling ages can contribute to the understanding of the tectonic processes and their duration in a multiphase orogeny. By integrating sedimentary, metamorphic and structural observations with both published and new AFT and ZFT ages, we aimed (i) to unravel the role of the Pelagonian zone and the adjacent AVAZ in the evolution of the Hellenides and (ii) to integrate in space and time the Eocene-to-Miocene cooling into compressional vs. extensional tectonics.

Our study identified four major cooling events: (i) variable in time and space, post-collisional cooling affecting Pelagonia, AVAZ and western Rhodope from 102 to ca. $68 \mathrm{Ma}$ as shown by ZFT ages and subsidence of marine basins over the Pelagonian and AVAZ units; (ii) fast cooling and erosion at ca. $68 \mathrm{Ma}$ attested by ZFT ages and increased coarse detritus shed from Pelagonia to the western AVAZ basins; (iii) fast cooling below $240^{\circ} \mathrm{C}$ from 24 to $16 \mathrm{Ma}$ in the footwall of a normal fault in central-eastern Pelagonia; (iv) fast cooling after $7 \mathrm{Ma}$ below ca. $80^{\circ} \mathrm{C}$ coeval with E-W to NE-SW trending normal fault zones in central-eastern Pelagonia.

\subsection{Tectonic setting and geological overview}

The Pelagonian zone, in the Internal Hellenides, is delimited by the AVAZ to the northeast and the External Hellenides to the southwest (Fig. 1a). After the Variscan orogeny and Permian-Triassic rifting, Pelagonia was part of a continental block bounded to the northeast by its passive margin (the AVAZ) and a seaway of the Tethys Ocean (e.g., Sharp and Robertson, 2006; Schenker et al., 2014). To the southwest, Pelagonia is delimited by the Pindos basin (e.g., Bernoulli and Laubscher, 1972).

The continental Precambrian basement of Pelagonia has been intruded by Carboniferous (late Variscan) and PermoTriassic (Tethys rifting) granitoids (Anders et al., 2007; Schenker et al., 2014); volcano-sedimentary rocks and carbonates are attributed to the cover of the crystalline rocks (e.g., Kilias et al., 2010). Carbonates, ultramafic rocks and metavolcanites of the AVAZ (schematically represented in Fig. 3) were tectonically imbricated with Jurassic-Early Cretaceous sediments and the package was in turn thrust onto Pelagonia (IGME, 1991; Gawlick et al., 2008; Chiari et al., 2013). Ophiolitic clasts in the Jurassic-Early Cretaceous sediments suggest obduction during sedimentation of an ocean that was located further northeast, in the Vardar realm s.l. (Bernoulli and Laubscher, 1972; Baumgartner, 1985; Bortolotti et al., 2003, 2008; Schmid et al., 2008; Chiari et al., 2012), before being transported southwestward as far as the Pindos basin west of Pelagonia (now the Vourinos and Pindos ophiolites, Fig. 1b). Alternative reconstructions claim that these Vardar s.l. and Vourinos-Pindos ophiolites represent two oceans: the Pindos ophiolites obducted from the southwest and the Vardar ophiolites obducted from the northeast (Smith et al., 1979; Jones and Robertson, 1991; Clift and Dixon, 1998; Smith and Rassios, 2003). In any case, plate

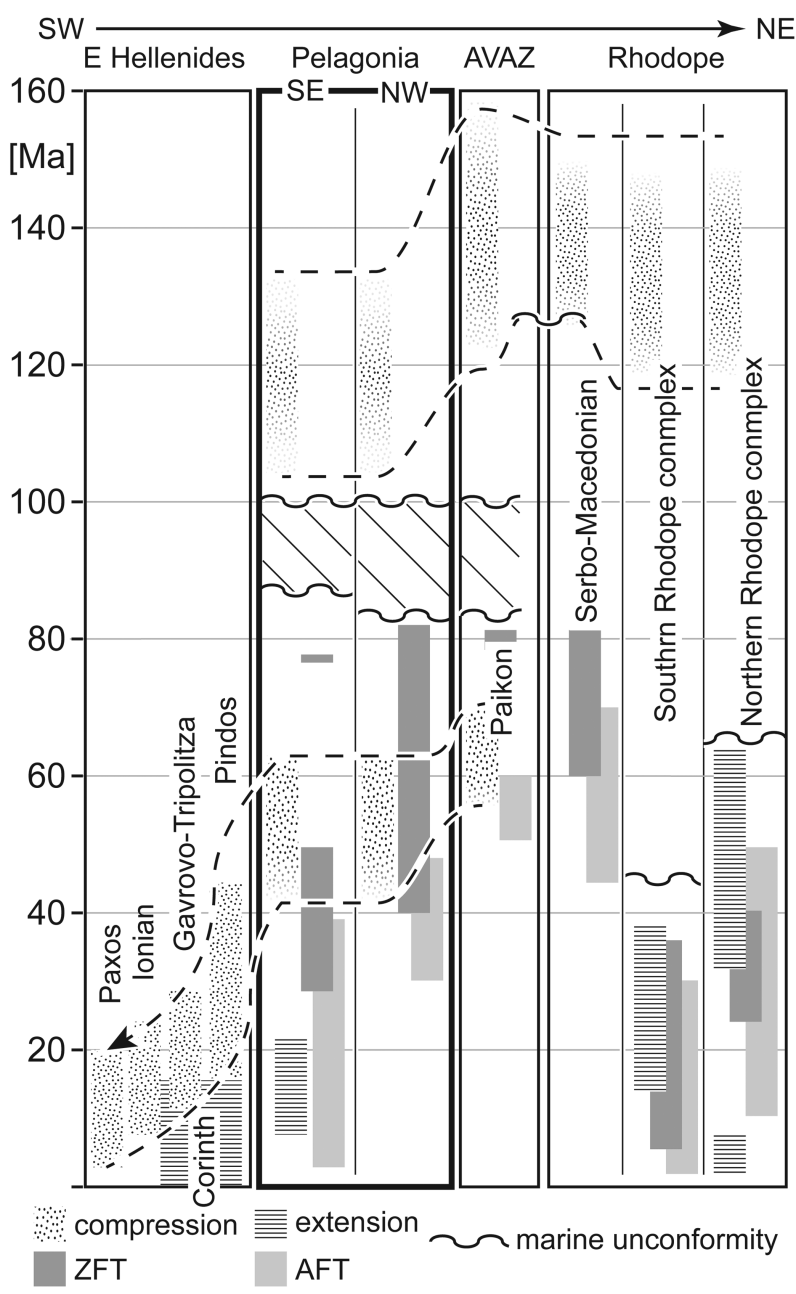

Figure 2. Correlation of zircon and apatite FT ages (references in Fig. 1) with main tectonic events. From southwest to northeast: tectonism of Paxos, Ionian, Gavrovo-Tripolitza and Pindos zones (typical localities of the first deposition of the synorogenic mass flow deposits) according to Papanikolaou (1997); Pelagonian unconformity and deformation according to Kilias et al. (2010) and Schenker et al. (2014), respectively; Paikon (Late Cretaceous/Early Tertiary window in the AVAZ) tectonism according to Bonneau et al. (1994) and Mercier and Vergely (1994); deformation and transgressions of Serbo-Macedonia (the westernmost continental fragment of the Rhodope) and the Southern and Northern Rhodope Complexes (two extensional metamorphic core complexes) according to Burg (2012) and Ivanova et al. (2015).

convergence started in the late Early Jurassic. NNE dipping subduction led to Late Jurassic-to-Early Cretaceous southwestward obduction onto Pelagonia of the ocean rooted to the east of the AVAZ (Schenker et al., 2014). Subsequent collision with Rhodope or Eurasia was responsible for the late Early Cretaceous tectonometamorphic event in Pelagonia (Yarwood and Dixon, 1977; Schermer et al., 1990; Lips et al., 1998; Schenker et al., 2014). The tectonically imbricated Pelagonian and AVAZ rocks were eroded and covered uncon- 

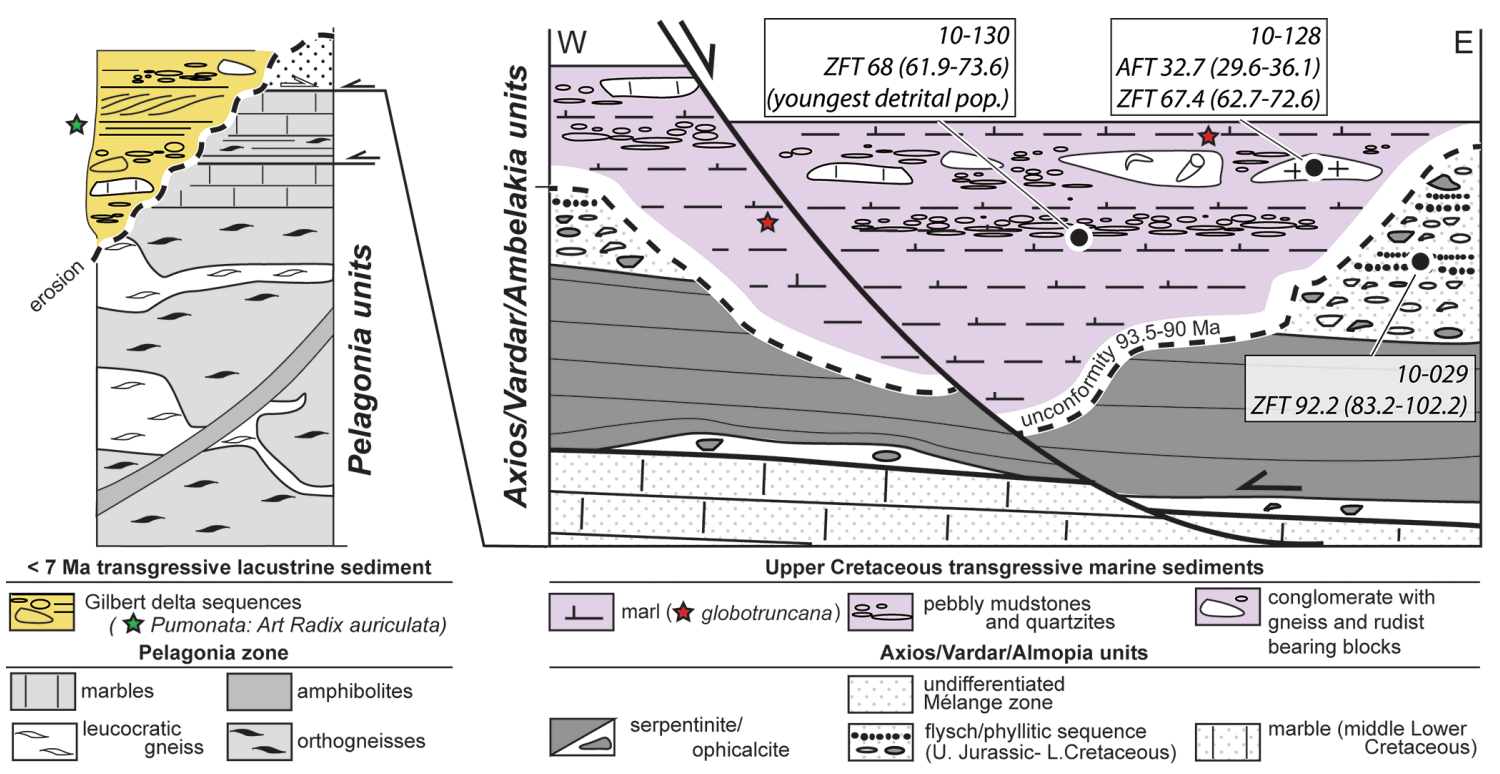

Figure 3. Tectonostratigraphic column of the Pelagonian zone and schematic field relationships of the AVAZ with sample locations and FT ages. FT ages shown with $2 \sigma$ confidence interval. The displacement along the normal fault in the AVAZ is unknown.

formably by transgressive Cenomanian-to-Lower Campanian (100 to $80 \mathrm{Ma}$ ) limestones passing upwards into deeperwater Paleocene turbidites (e.g., Mercier and Vergely, 1994; Papanikolaou, 2009). Maastrichtian-Eocene (ca. 70-38 Ma) mass flows marked the beginning of a second shortening event (Fig. 2) that migrated from the AVAZ to the southwestvergent accretionary system of the External Hellenides in Eocene-Miocene times (38-ca.15 Ma; Jacobshagen et al., 1978). Oligocene-Miocene (post $24 \mathrm{Ma}$ ) extension (Le Pichon et al., 1979; Brun and Faccenna, 2008) and related fast cooling were attested only in southeastern Pelagonia (Schermer et al., 1990; Lecassin et al., 2007; Coutand et al., 2014). Basins to the west (Mesohellenic Trough) and east (Axios Basin, Fig. 1) of Pelagonia were filled with marine colluvialproluvial sediments that show a complex tectonosedimentary history (Roussos, 1994; Ferrière et al., 2004). Late Mioceneto-Pleistocene (post $7 \mathrm{Ma}$ ) coal and lacustrine sediments locally covered the Pelagonian zone (Koukouzas et al., 1979; Mavridou et al., 2003; Steenbrink et al., 2006).

The regional main foliation in the orthogneisses and marbles of Pelagonia defines a 20 by $20 \mathrm{~km}^{2}$ dome with SW and NE flanks steeper than the NW and SE ones (Figs. 4 and 5). Metamorphic grade evolves from amphibolite facies in the core to greenschist facies close to the flanks of the dome. A prominent, top-to-the-ENE normal shear zone with both ductile and brittle deformation features separates Pelagonia from the thrust sheets of the AVAZ along the ENE flank of the dome (Fig. 5). Within the dome, a number of discrete shear zones with top-to-the-NE sense-of-shear overprint the former regional foliation and associated top-to-the-SW sense of shear, which are attributed to the late Early Cretaceous collision (Schenker et al., 2014).
Foliation in the low-grade AVAZ imbricates is subparallel to the lithological contacts. It dips in general to the $\mathrm{E}$ and locally to the $\mathrm{W}$ due to an antiform (rollover?) close to the contact with the Pelagonian rocks (Fig. 5). Shear bands and SWvergent drag folds indicate top-to-the-SW kinematics. Late and widely distributed top-to-the-E normal faults (Fig. 5) cut both the low-grade imbricates and the Cenomanian-toMaastrichtian unconformable sediments (Fig. 3).

The youngest regionally distributed structures are $\mathrm{E}-\mathrm{W}$ to NE-SW striking steep faults that bound the Late MiocenePliocene Ptolemais-Kozani basins (Fig. 4, Koukouzas et al., 1979; Steenbrink et al., 2006). These normal faults displaced and placed lacustrine sediments at different elevations (Fig. 6). In 1995, an earthquake of magnitude 6.6 demonstrated recent activity of these faults (Pavlides et al., 1995).

\subsection{Previously published low-temperature thermochronometric data}

We present existing information in decreasing order of closure temperatures for mean cooling rates of $10^{\circ} \mathrm{C} \mathrm{Ma}^{-1}$ from $240^{\circ} \mathrm{C}$ for $\mathrm{ZFT}, 180^{\circ} \mathrm{C}$ for $\mathrm{ZHe}$ and $110^{\circ} \mathrm{C}$ for AFT to $70^{\circ} \mathrm{C}$ for AHe (e.g., Reiners and Brandon, 2006).

ZFT ages (Most et al., 2001; Most, 2003; Vamvaka et al., 2010) range between 86 and $61 \mathrm{Ma}$ in the eastern part of north Pelagonia and span between 53 and $39 \mathrm{Ma}$ in the western part (Fig. 1b). To the south, they vary from 76 to $32 \mathrm{Ma}$ (Most et al., 2001; Most, 2003; Vamvaka et al., 2010). Younger, 35-32 Ma old ZFT ages are located close to the Olympos window (Fig. 1b). In the AVAZ, ZFT ages are 80 Ma (Most, 2003). The western Rhodope yielded $72 \mathrm{Ma}$ ZFT ages (Kounov et al.,2015). 


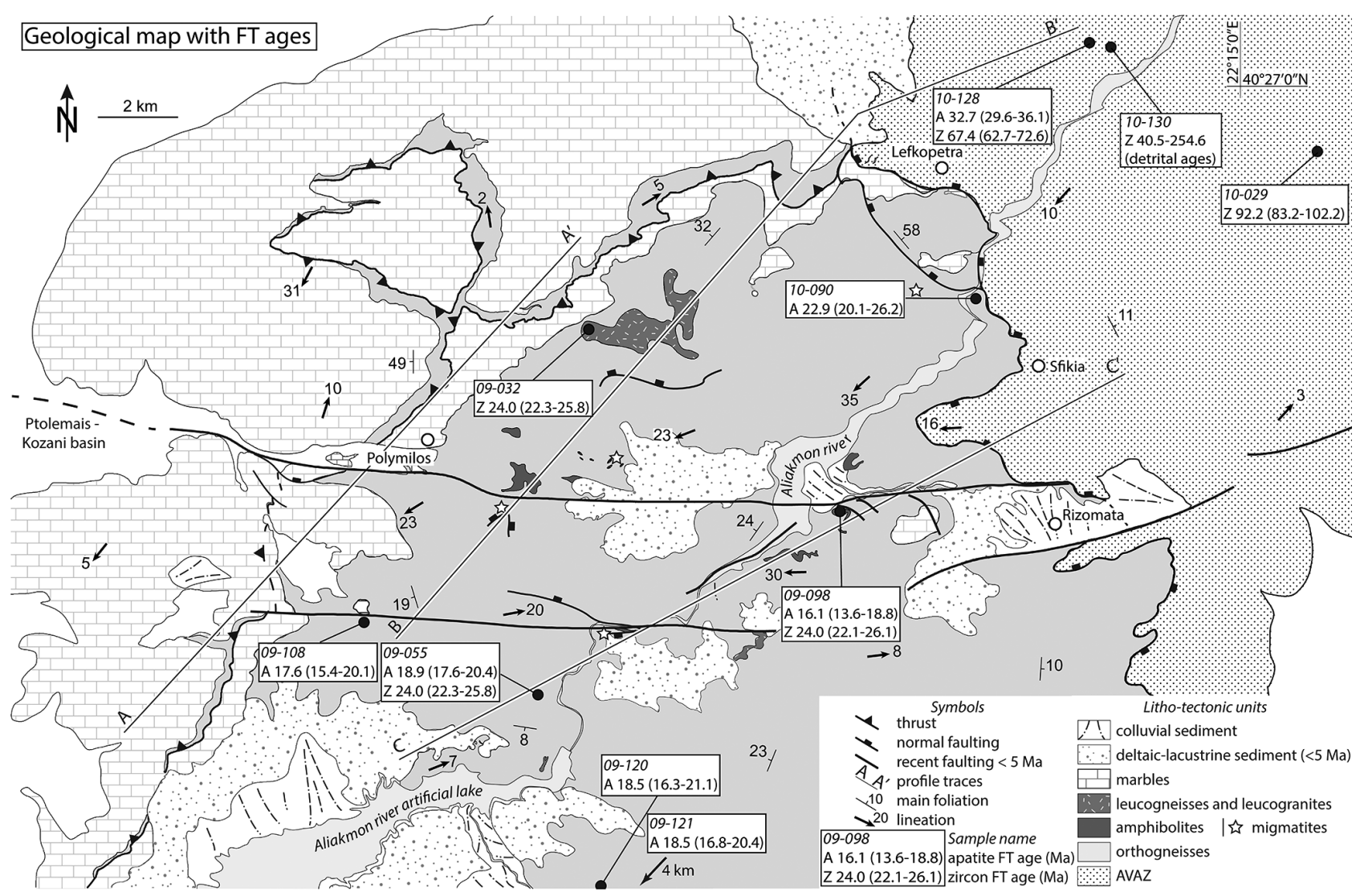

Figure 4. Location and age of FT samples (pooled age and $68 \%$ confidence interval) on the geological map (located in Fig. 1) of the eastern Pelagonian gneiss dome (Schenker, 2014). For the detrital zircons of sample 10-130, the range of single-grain ages is reported.

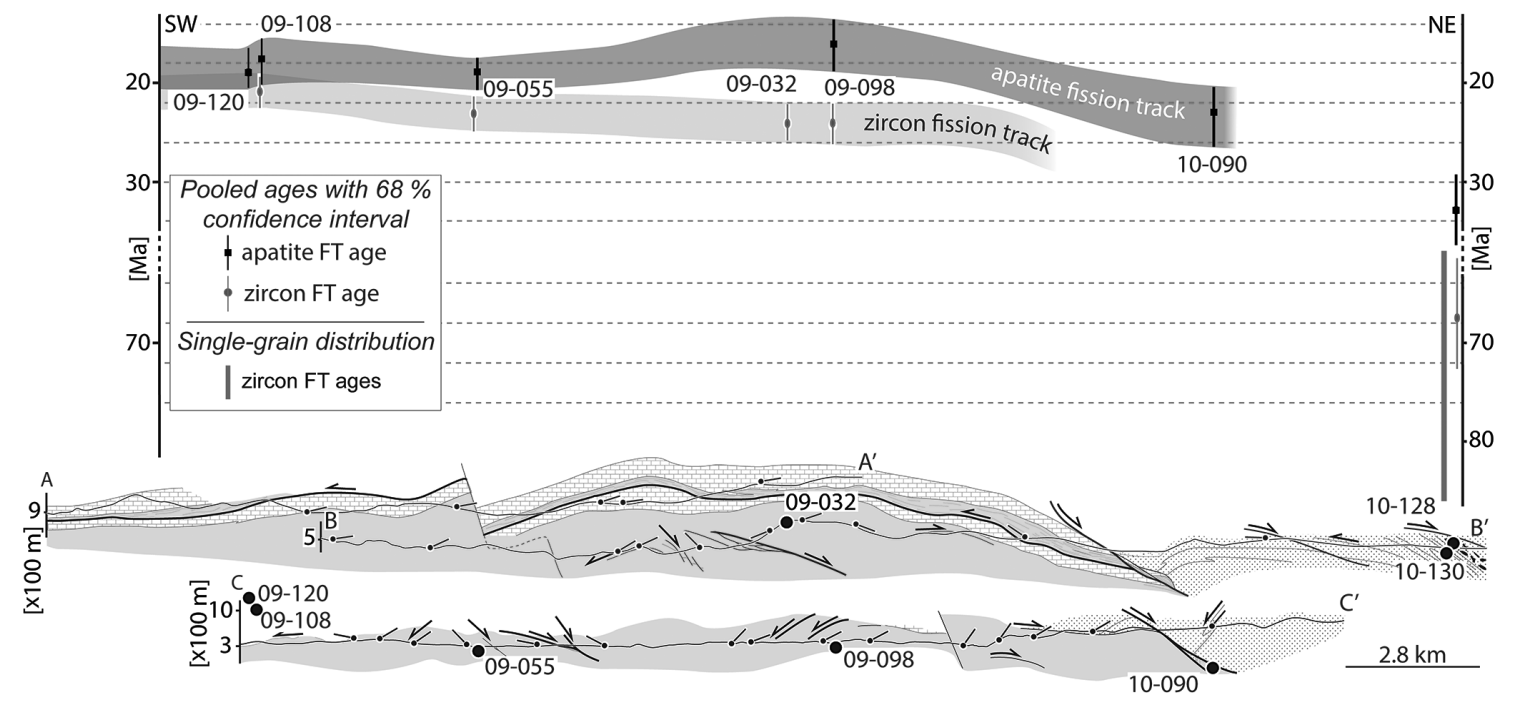

Figure 5. AFT and ZFT ages along three transects across the eastern Pelagonia gneiss dome. For the location of the transects see Fig. 2.

ZHe in southern Pelagonia yields 53-36 Ma ages to the west and 30-20 Ma close to and within the Olympos window (Coutand et al., 2014). To the south of the Olympos window $\mathrm{ZHe}$ ages are as young as $12 \mathrm{Ma}$. ZHe ages are not plotted in the regional compilation (Fig. 1) since they are available in southern Pelagonia only and our data do not include such analyses. Nevertheless, they are implicitly taken into account as they have a similar age distribution as the ZFT ages. 
Table 1. Pooled ages calculated using dosimeter glass CN5 and CN1 for zircons and apatites, respectively. $\rho_{\mathrm{S}}$ is the spontaneous track densities measured in internal mineral surfaces; $N_{\mathrm{S}}$ is the total number of spontaneous tracks; $\rho_{\mathrm{i}}$ and $\rho_{\mathrm{d}}$ are the induced and dosimenter track densities on external mica detectors; $N_{\mathrm{i}}$ and $N_{\mathrm{d}}$ are the total numbers of tracks; $P\left(\chi^{2}\right)$ is the probability of obtaining $\chi^{2}$ value for $y$ degrees of freedom (where $y=$ number of crystals -1 ).

\begin{tabular}{|c|c|c|c|c|c|c|c|c|c|c|c|c|c|c|}
\hline Sample & Unit/rock type & Coordinates & $\begin{array}{c}\text { Elevation } \\
{[\mathrm{m}]}\end{array}$ & $\begin{array}{l}\text { No. of } \\
\text { grains }\end{array}$ & $\begin{array}{c}\rho_{\mathrm{d}} \\
{[\text { tracks cm}} \\
\end{array}$ & $\begin{array}{c}\rho_{\mathrm{S}} \\
{\left[\text { tracks cm}{ }^{-2}\right]}\end{array}$ & $N_{\mathrm{s}}$ & $\begin{array}{c}\rho_{\mathrm{i}} \\
{[\text { tracks cm}} \\
\left.\mathrm{cm}^{-2}\right]\end{array}$ & $N_{\mathrm{i}}$ & $\begin{array}{c}P\left(\chi^{2}\right) \\
{[\%]}\end{array}$ & $\begin{array}{l}\text { Pooled age } \\
68 \% \text { CI [Ma] }\end{array}$ & $-2 \sigma$ & $+2 \sigma$ & Local $\zeta$-CN \\
\hline \multicolumn{15}{|c|}{ Zircon FT age } \\
\hline 09-032 & $\begin{array}{l}\text { Pelagonian basement/ } \\
\text { leucogneiss }\end{array}$ & $\begin{array}{l}\mathrm{N} 40^{\circ} 23^{\prime} 45.4^{\prime \prime} \\
\mathrm{E} 022^{\circ} 06^{\prime} 18.5^{\prime \prime}\end{array}$ & 1330 & 20 & $3.51 \mathrm{E}+05$ & $6.14 \mathrm{E}+06$ & 581 & $6.39 \mathrm{E}+06$ & 605 & 25.4 & 24 & 1.7 & 1.9 & $142.57 \pm 5.95$ \\
\hline 09-055 & $\begin{array}{l}\text { Pelagonian basement/ } \\
\text { granodiorite }\end{array}$ & $\begin{array}{l}\mathrm{N} 40^{\circ} 19^{\prime} 11.6^{\prime \prime} \\
\mathrm{E} 022^{\circ} 05^{\prime} 53.8^{\prime \prime}\end{array}$ & 320 & 20 & $3.33 \mathrm{E}+05$ & $8.05 \mathrm{E}+06$ & 666 & $8.27 \mathrm{E}+06$ & 684 & 18.5 & 23.1 & 1.6 & 1.7 & $142.57 \pm 5.95$ \\
\hline 09-098 & $\begin{array}{l}\text { Pelagonian basement/ } \\
\text { leucogneiss }\end{array}$ & $\begin{array}{l}\mathrm{N} 40^{\circ} 21^{\prime} 21.4^{\prime \prime} \\
\mathrm{E} 022^{\circ} 09^{\prime} 39.5^{\prime \prime}\end{array}$ & 250 & 20 & $3.36 \mathrm{E}+05$ & $4.75 \mathrm{E}+06$ & 429 & $4.72 \mathrm{E}+06$ & 427 & 95.8 & 24 & 1.9 & 2.1 & $142.57 \pm 5.95$ \\
\hline 09-108 & $\begin{array}{l}\text { Pelagonian basement/ } \\
\text { granodioritic gneiss }\end{array}$ & $\begin{array}{l}\mathrm{N} 40^{\circ} 19^{\prime} 50.6^{\prime \prime} \\
\mathrm{E} 022^{\circ} 03^{\prime} 19.4^{\prime \prime}\end{array}$ & 1020 & 20 & $3.45 \mathrm{E}+05$ & $5.08 \mathrm{E}+06$ & 479 & $6.02 \mathrm{E}+06$ & 568 & 61.6 & 20.7 & 1.5 & 1.7 & $142.57 \pm 5.96$ \\
\hline $10-029$ & $\begin{array}{l}\text { AVAZ/late Upper } \\
\text { Jurassic-Cretaceous conglomerate }\end{array}$ & $\begin{array}{l}\mathrm{N} 40^{\circ} 26^{\prime} 10.8^{\prime \prime} \\
\mathrm{E} 022^{\circ} 16^{\prime} 00.7^{\prime \prime}\end{array}$ & 760 & 16 & $4.56 \mathrm{E}+05$ & $7.90 \mathrm{E}+06$ & 447 & $2.76 \mathrm{E}+06$ & 156 & 25.3 & 92.2 & 9 & 10 & $142.57 \pm 5.95$ \\
\hline $10-128$ & $\begin{array}{l}\text { AVAZ/gneissic block in } \\
\text { Upper Cretaceous conglomerate }\end{array}$ & $\begin{array}{l}\mathrm{N} 40^{\circ} 27^{\prime} 45.1^{\prime \prime} \\
\mathrm{E} 022^{\circ} 12^{\prime} 26.7^{\prime \prime}\end{array}$ & 530 & 21 & $4.55 \mathrm{E}+05$ & $9.22 \mathrm{E}+06$ & 901 & $4.41 \mathrm{E}+06$ & 431 & 15 & 67.4 & 4.8 & 5.2 & $142.57 \pm 5.95$ \\
\hline $10-130$ & $\begin{array}{l}\text { AVAZ/Upper Cretaceous } \\
\text { conglomerate }\end{array}$ & $\begin{array}{l}\mathrm{N} 40^{\circ} 27^{\prime} 37.6^{\prime \prime} \\
\mathrm{E} 022^{\circ} 13^{\prime} 10.4^{\prime \prime}\end{array}$ & 440 & 27 & $4.59 \mathrm{E}+05$ & $4.52 \mathrm{E}+06$ & 881 & $1.93 \mathrm{E}+06$ & 376 & 1.7 & 76.2 & 5.7 & 6.2 & $142.57 \pm 5.96$ \\
\hline \multicolumn{15}{|c|}{ Apatite FT ages } \\
\hline 09-055 & $\begin{array}{l}\text { Pelagonian basement/ } \\
\text { granodioritic gneiss }\end{array}$ & $\begin{array}{l}\mathrm{N} 40^{\circ} 19^{\prime} 11.6^{\prime \prime} \\
\mathrm{E} 022^{\circ} 05^{\prime} 53.8^{\prime \prime}\end{array}$ & 320 & 27 & $1.37 \mathrm{E}+06$ & $5.60 \mathrm{E}+05$ & 326 & $6.59 \mathrm{E}+06$ & 3838 & 2.8 & 19.5 & 1.4 & 1.5 & $335.93 \pm 14.96$ \\
\hline 09-098 & $\begin{array}{l}\text { Pelagonian basement/ } \\
\text { leucogneiss }\end{array}$ & $\begin{array}{l}\mathrm{N} 40^{\circ} 21^{\prime} 21.4^{\prime \prime} \\
\mathrm{E} 022^{\circ} 09^{\prime} 39.5^{\prime \prime}\end{array}$ & 240 & 38 & $1.34 \mathrm{E}+06$ & $8.84 \mathrm{E}+04$ & 48 & $1.24 \mathrm{E}+06$ & 673 & 99.6 & 16.1 & 2.4 & 2.7 & $335.93 \pm 14.96$ \\
\hline 09-108 & $\begin{array}{l}\text { Pelagonian basement/ } \\
\text { granodioritic gneiss }\end{array}$ & $\begin{array}{l}\mathrm{N} 40^{\circ} 19^{\prime} 50.6^{\prime \prime} \\
\mathrm{E} 022^{\circ} 03^{\prime} 19.4^{\prime \prime}\end{array}$ & 1020 & 24 & $1.47 \mathrm{E}+06$ & $1.83 \mathrm{E}+05$ & 69 & $2.57 \mathrm{E}+06$ & 971 & 66.4 & 17.6 & 2.2 & 2.5 & $335.93 \pm 14.96$ \\
\hline $09-120$ & $\begin{array}{l}\text { Pelagonian basement/ } \\
\text { leucogneiss }\end{array}$ & $\begin{array}{l}\mathrm{N} 40^{\circ} 16^{\prime} 43.3^{\prime \prime} \\
\mathrm{E} 022^{\circ} 06^{\prime} 50.8^{\prime \prime}\end{array}$ & 1000 & 23 & $1.42 \mathrm{E}+06$ & $2.67 \mathrm{E}+05$ & 73 & $3.46 \mathrm{E}+06$ & 947 & 94.5 & 18.5 & 2.2 & 2.6 & $335.93 \pm 14.96$ \\
\hline $09-121 b$ & $\begin{array}{l}\text { Pelagonian basement/ } \\
\text { granodioritic gneiss }\end{array}$ & $\begin{array}{l}\mathrm{N} 40^{\circ} 13^{\prime} 37.0^{\prime \prime} \\
\mathrm{E} 022^{\circ} 06^{\prime} 34.4^{\prime \prime}\end{array}$ & 1200 & 25 & $1.31 \mathrm{E}+06$ & $5.23 \mathrm{E}+05$ & 131 & $6.30 \mathrm{E}+06$ & 1577 & 68.9 & 18.5 & 1.7 & 1.9 & $339.54 \pm 12.53$ \\
\hline $10-090$ & $\begin{array}{l}\text { Pelagonian basement/ } \\
\text { granodioritic gneiss }\end{array}$ & $\begin{array}{l}\mathrm{N} 40^{\circ} 24^{\prime} 15.3^{\prime \prime} \\
\mathrm{E} 022^{\circ} 11^{\prime} 33.6^{\prime \prime}\end{array}$ & 160 & 25 & $1.23 \mathrm{E}+06$ & $2.21 \mathrm{E}+05$ & 69 & $2.03 \mathrm{E}+06$ & 633 & 23.2 & 22.9 & 2.8 & 3.2 & $339.54 \pm 12.53$ \\
\hline $10-128$ & $\begin{array}{l}\text { Vardar/gneissic block in } \\
\text { Upper Cretaceous conglomerate }\end{array}$ & $\begin{array}{l}\mathrm{N} 40^{\circ} 27^{\prime} 45.1^{\prime \prime} \\
\mathrm{E} 022^{\circ} 12^{\prime} 26.7^{\prime \prime}\end{array}$ & 530 & 20 & $1.60 \mathrm{E}+06$ & $3.76 \mathrm{E}+05$ & 131 & $3.13 \mathrm{E}+06$ & 1091 & 13.7 & 32.7 & 3.1 & 3.4 & $339.54 \pm 12.53$ \\
\hline
\end{tabular}

AFT ages (Fig. 1c) are 46-25 Ma in northern Pelagonia (Most et al., 2001; Most, 2003), 41-25 Ma in the southwest (Vamvaka et al., 2010; Coutand et al., 2014) and 18-11 Ma in the southeast (Most, 2003; Coutand et al., 2014). The few data in the AVAZ are 60-47 Ma (Most et al., 2001; Most, 2003). The western Rhodope also yielded AFT ages from 68 to $47 \mathrm{Ma}$ (Kydonakis et al., 2014).

AHe ages in southern Pelagonia show a general eastward younging trend from 26 to $10 \mathrm{Ma}$ (Coutand, 2014). This trend is associated with rapid cooling between 12 and $6 \mathrm{Ma}$ around and in the Olympos window (Coutand et al., 2014).

Detrital apatites from Eocene-to-Miocene sediments of the southern Mesohellenic trough (Fig. 1b) show two age populations: at ca. $65 \mathrm{Ma}$ and, more prominently, at ca. $40 \mathrm{Ma}$ (Vamvaka et al., 2010).

\section{New zircon and apatite fission-track dating}

\subsection{Method}

The FT technique has been used to trace the low-temperature history of rocks collected along a SW-NE transect from both the footwall and hanging wall of major ductile shear zones to date fault activity and deformation from age differences between footwall and hanging wall rocks (Figs. 3 and 5). Elevations of sampling sites were recorded (Table 1 and Fig. 5). FT ages were calculated with the $\zeta$ method (Hurford, 1990), $\zeta$ values are listed in Table 1.
Zircons and apatites were extracted with acoustic shock waves produced in the SELFRAG apparatus (http://www. selfrag.com), ETH-Zürich. Standard heavy-liquid and magnetic separation delivered fractions enriched in apatite and zircon (Naeser, 1976). Zircon grains were mounted in teflon discs and apatites in epoxy. The mounts were polished to expose the internal surfaces of minerals and etched to visualize tracks. Zircons were etched for $25-28 \mathrm{~h}$ with $\mathrm{NaOH}-\mathrm{KOH}$ in a eutectic melt at $220^{\circ} \mathrm{C}$. Apatites were etched for $20 \mathrm{~s}$ in $5.5 \mathrm{M} \mathrm{HNO}_{3}$ at a controlled temperature of $21^{\circ} \mathrm{C}$. All samples were irradiated at the Oregon State University Reactor, along with low-U muscovite discs as external detectors, CN1 as fluence dosimeter for zircons or $\mathrm{CN} 5$ as fluence dosimeter for apatites (Durango and Fish Canyon Tuff standards). After irradiation, the external detectors were etched with $40 \% \mathrm{HF}$ for $45 \mathrm{~min}$, allowing visualization of the induced tracks.

\subsection{Sample location and description}

Sample location and details are given in Figs. 4 and 5 and Table 1.

\subsubsection{Pelagonia}

Samples 09-108, 09-120, 09-121, 09-055, 09-932, 09-098 and 10-090 are granitoids from the Pelagonian zone. They contain quartz, plagioclase, biotite or chlorite, epidote, white mica, sphene and hornblende or actinolite. These granitoids are characterized by gneissic textures varying from non- 


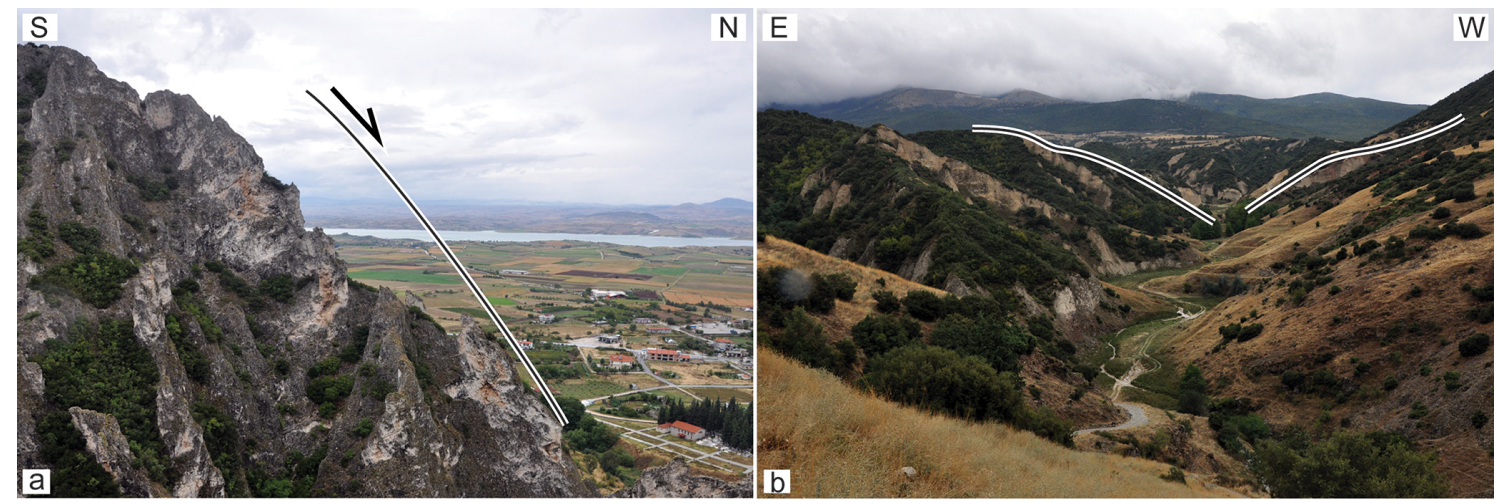

Figure 6. Topographic expression of the Servia fault, $10 \mathrm{~km} \mathrm{SW}$ of the working area $\left(40^{\circ} 10^{\prime} 37^{\prime \prime} \mathrm{N}, 21^{\circ} 59^{\prime} 50^{\prime \prime} \mathrm{E}\right)$. (a) Erosion features on the fault scarp; on the horizon, the Kozani plain (ca. $280 \mathrm{~m}$ above sea level) filled with Pliocene to recent lacustrine sediments found in the footwall at ca. $800 \mathrm{~m}$ above sea level. (b) Concave-up hillslopes in valleys in the footwall of the Servia normal fault, suggesting fast recent uplift.

foliated to mylonitic and mineral assemblages attesting different metamorphic grades from amphibolite to greenschist facies.

\subsubsection{AVAZ}

Sample 10-029 from the AVAZ is a grain-supported conglomerate that belongs to the imbricated Upper JurassicLower Cretaceous "Flysch-Phyllitic Series" (IGME, 1991). Clasts of $\mathrm{Cr}$ spinel and hemicrystalline mafic fragments (likely of ophiolitic origin) suggest that these sediments were deposited on the AVAZ in the front of exposed ophiolites, likely those that are now obducted over the AVAZPelagonian system. Chlorite blasts in sample 10-029 indicate low-grade metamorphism (Fig. 7a).

The samples 10-130 and 10-128 were collected in the upper beds of a ca. $350 \mathrm{~m}$ thick sedimentary sequence unconformably covering the AVAZ imbricates (Fig. 3). Sample 10130 is a matrix-supported conglomerate with a carbonate matrix and pebbles of quartz and feldspar aggregates, serpentinites and schists. Sample $10-128$ is a single, ca. $50 \mathrm{~cm}$ in diameter orthogneissic boulder from a clastic layer stratigraphically above sample 10-130 (Fig. 3). Sample 10-128 and 10-130 are not metamorphic. The sedimentary sequence containing samples $10-130$ and $10-128$ is characterized by marls intercalated with pebbly mudstones, carbonate olistoliths containing Late Cretaceous rudists (Appendix A) and conglomerates (Fig. 3) showing an up-sequence increase and coarsening of the detritus. The rudists are typical for the Pelagonian and AVAZ fauna, attesting that the studied clastics are derived from carbonate platforms that partly covered these zones and not from the Rhodope, where no rudists were found (cf. Viquesnel, 1853; Sharp and Robertson, 2006). Marls covering unconformably the AVAZ thrust sheets contain the Turonian species Helvetoglobotruncana helvetica (Figs. 3 and 7b), setting the lower time bracket between 93.5 and $90 \mathrm{Ma}$ (Bolli, 1945). The upper age limit of the stratigraphic column is $\geq 65 \mathrm{Ma}$ based on the Late Cretaceous Globotruncana sp. in marls (Figs. 3 and 7c).

\subsection{Results}

\subsubsection{Zircon fission track}

The pooled ZFT ages of the granitoids vary between 24 and 20.7 Ma (Figs. 4 and 5 and Table 1) with no discernible difference along the SW-NE transect. The results show no relationship between age and elevation (Fig. 1 and Table 1). The $\chi^{2}$ probability $\left(P\left(\chi^{2}\right)\right)$ ranged between $18.5 \%$ and $95.8 \%$, which is well above the $5 \%$ threshold of the $P\left(\chi^{2}\right)$ test; this indicates that each sample consists of a single age population (Galbraith, 1981).

The ZFT pooled ages in the three AVAZ sedimentary rocks yielded ages between 92.2 and $67.4 \mathrm{Ma}$ (Figs. 4 and 5 and Table 1). ZFT ages in the low metamorphic-grade Jurassic-toEarly Cretaceous sediments of sample 10-029 gave a single age population of $92.2(-9+10)$ Ma with a $P\left(\chi^{2}\right)$ value of $25.3 \%$. The age density histogram (Fig. 8 a) exhibits a broad scatter of data from ca. 50 to $300 \mathrm{Ma}$. The sparse amount of countable zircons from this sample $(n=16$, Table 1$)$ prevented determining with statistical methods whether its ZFT ages are reset or detrital. Nevertheless, the metamorphic growth of chlorite indicates peak temperatures above $250^{\circ} \mathrm{C}$ (Spear, 1995) that have either partially or totally reset sample 10-029, which subsequently cooled below $240^{\circ} \mathrm{C}$ at $92.2(+10-9)$ Ma. The gneissic boulder (10-128) in the Upper Cretaceous sedimentary unit, which lies unconformably on the thrust sheets containing sample 10-029, yielded a single age population at $67.4(-4.8+5.2) \mathrm{Ma}\left(P\left(\chi^{2}\right)=15 \%\right)$. In the same sedimentary sequence, the unmetamorphosed rocks of sample 10-130 showed a pooled age of $76.2(-5.7$ $+6.2)$ Ma with a $P\left(\chi^{2}\right)$ value of $1.7 \%$, indicating that the age distribution consists of multiple populations. Using the Binomfit computer program (Brandon, 1996), two pop- 

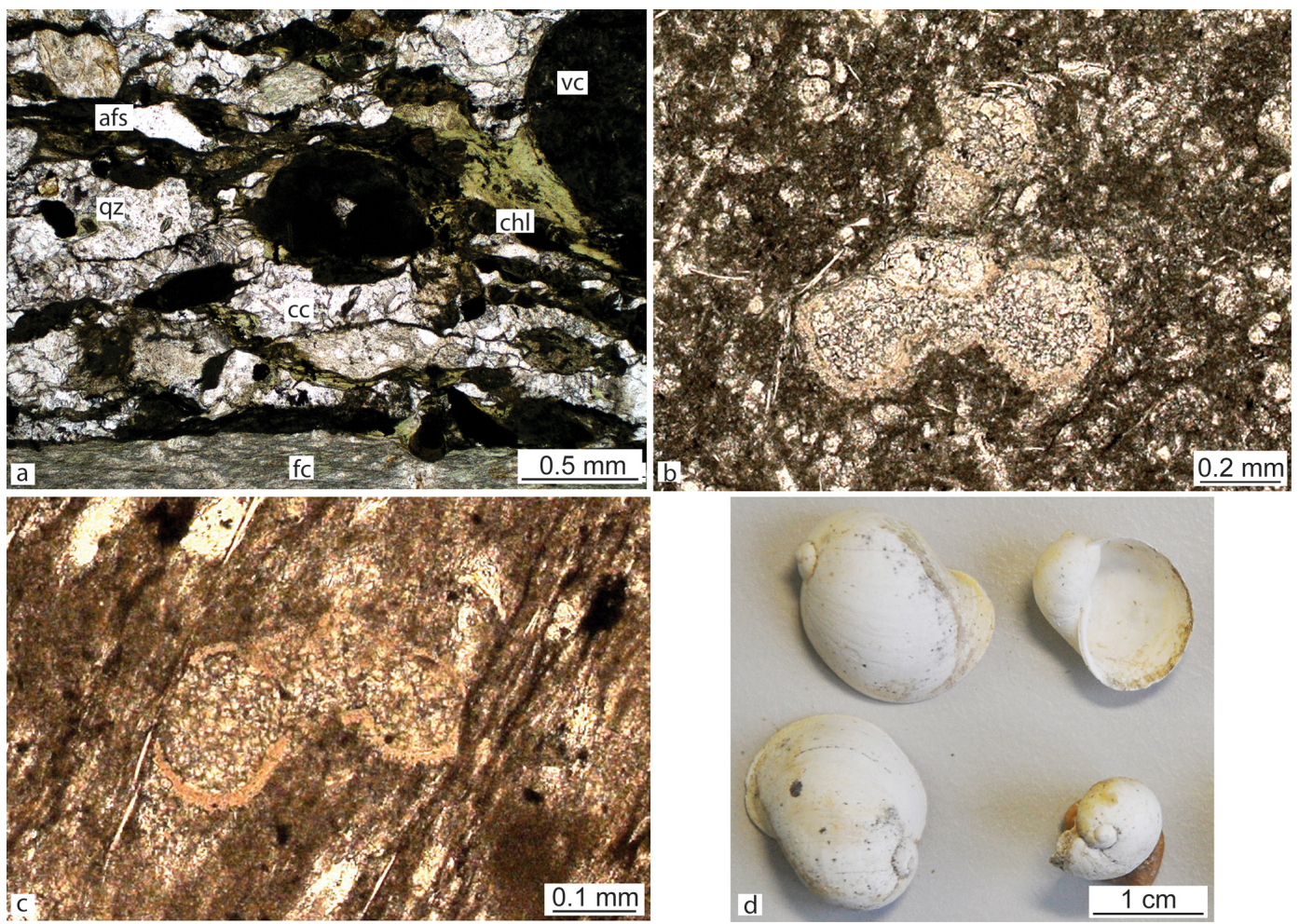

Figure 7. Photomicrographs of thin sections: (a) metamorphic conglomerate, sample 10-029, with metamorphic chlorite (chl) in a calcitic matrix. Other clasts: fc is felsic clast, afs is feldspar, qz is quartz and vc is volcanic clast; (b) Turonian Helvetoglobotruncana helvetica (93.5 and $90 \mathrm{Ma}$ ) in marls on the transgressive discordance; (c) Late Cretaceous ( $>66 \mathrm{Ma}$ ) Globotruncana sp. in the marls intercalated with sample 10-128; (d) Pliocene to recent art Radix Auriculata found in the lacustrine sediments.

a) $10-029$

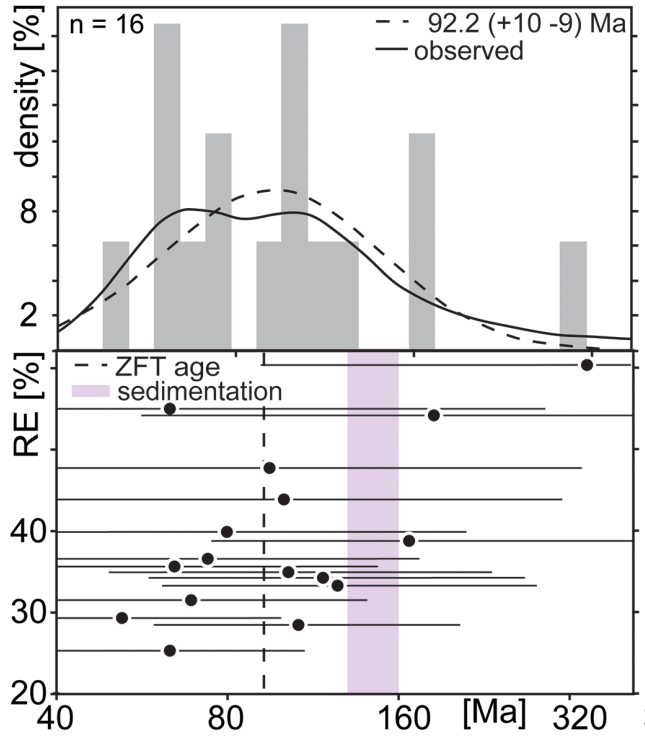

b) $\mathbf{1 0 - 1 3 0}$

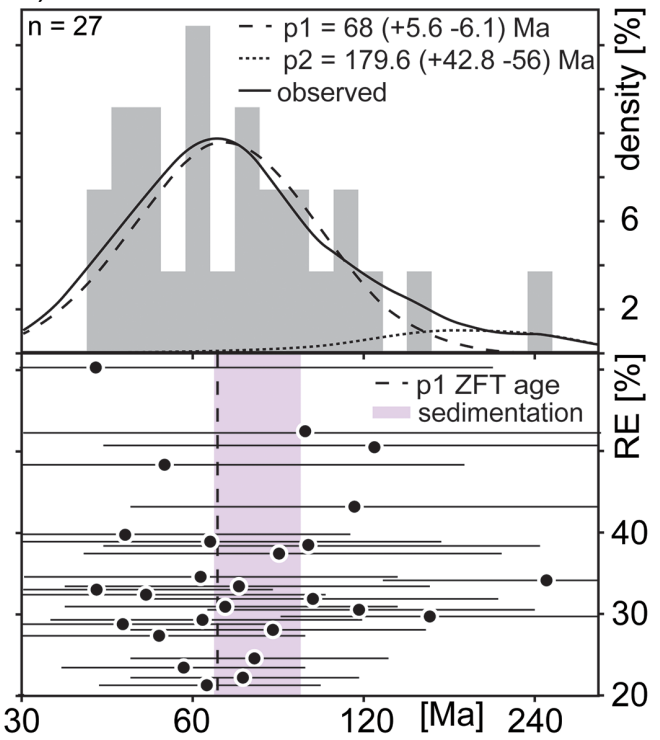

Figure 8. Age density histograms for "detrital" FT ages with distribution curves ( $n$ is number of grain measured, $p$ is population, RE is relative error in \%) calculated with Binomfit (Brandon, 1996). (a) Zircon age distribution of grain-supported conglomerate 10-029 belonging to the uppermost Jurassic-Lower Cretaceous "flysch" of the AVAZ (IGME, 1991). (b) Zircon age distribution from non-metamorphic, Upper Cretaceous conglomerate (10-130). 

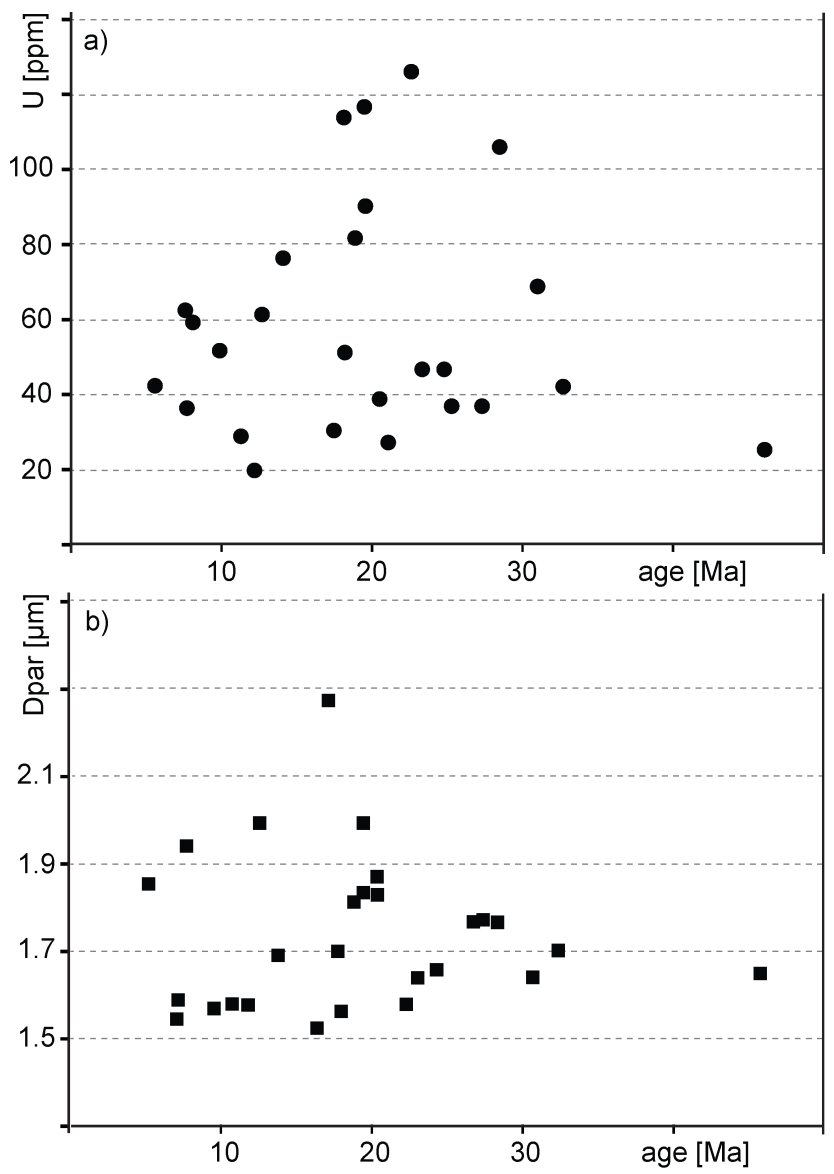

Figure 9. Plots of single apatite measurements of sample 09-055; (a) U concentration vs. age and (b) dpar vs. age.

ulations were estimated: (i) a Late Cretaceous one at 68 $(-6.1+5.6) \mathrm{Ma}$ and (ii) a Early Jurassic one at $179.6(-56$ $+42.8)$ Ma (Fig. 8b).

\subsubsection{Apatite fission track}

The AFT ages of granitoids from the Pelagonian zone are distributed between 22.9 and 16.1 Ma. As the ZFT ages, these ages show no correlation with elevation and no discernible difference along the profile (Fig. 5 and Table 1). Only the easternmost sample (10-090, Figs. 4 and 5, pooled age $=22.9 \mathrm{Ma}$ ) is significantly older than the others: its upper $68 \%$ confidence interval $(\mathrm{CI})$ is $1.3 \mathrm{Ma}$ older than the lower $68 \%$ CI of the closest sample to the west (09-098, pooled age $=16.1 \mathrm{Ma}$ ). The $P\left(\chi^{2}\right)$ values of the granitoid AFT cooling ages were between 2.8 and $99.6 \%$. Exceptionally for magmatic rocks, sample 09-055 failed the $\chi^{2}$ test $\left(P\left(\chi^{2}\right)=2.8 \%\right)$. The grain age distribution of this sample was strongly affected by one grain with an old age (46.1 Ma) (Fig. 9). The omission of this outlier grain resulted in a $P\left(\chi^{2}\right)$ value of $17 \%$ without affecting significantly either the central or the pooled age, which remain unchanged within error $(17.6,-1.4+1.5 \mathrm{Ma})$. Moreover, apatites of sample 09055 showed a high spread of $\mathrm{U}$ concentration with values up to $126 \mathrm{ppm}$ and $D_{\text {par }}$ values ranging between 1.5 and $2.2 \mu \mathrm{m}$ (Fig. 9). The $D_{\text {par }}$ is the arithmetic mean maximum diameter of FT etch figures, and this parameter is used to infer the relative resistance to annealing (Burtner et al., 1994; Carlson et al., 1999). The relative wide range of $D_{\text {par }}$ values of sample 09-055 could partly explain the spread of its grain ages resulting in a low $P\left(\chi^{2}\right)$ value. The large age distribution of this sample may also be due to its high spread of $U$ concentration that causes significant radiation damage of apatites. Although no experimental data exist on the influence of radiation damage on the FT annealing kinetics in apatites, it is commonly argued that it may play a role (Carlson et al., 1999). Because both the $D_{\text {par }}$ and $\mathrm{U}$ concentration values of these samples hint to compositional heterogeneity and the ZFT age of this sample is consistent with a single population centered at 23.1 Ma, we conclude that its AFT age distribution reflects variable annealing resistance and does not relate to partial-resetting conditions.

The only AFT age from the AVAZ (10-128) is $32.7(+3.4$ $-3.1)$ Ma with a $P\left(\chi^{2}\right)$ value of $13.7 \%$. As discussed in the previous paragraph, sample $10-128$ is a gneissic boulder in the unmetamorphosed sediments containing Late Cretaceous Globotruncana (Figs. 3 and 7c). Therefore, young apatites in the $\geq 65 \mathrm{Ma}$ sediments have been totally reset at ca. $33 \mathrm{Ma}$ or earlier, and they cooled below $110^{\circ} \mathrm{C}$ (AFT closure temperature) at 32.7 Ma. The ZFT age of this sample was not reset, which implies that temperatures that have reset apatite did not rise beyond $220-240^{\circ} \mathrm{C}$.

\subsubsection{Inverse modeling of fission-track lengths}

Thermal history reconstructions were performed using inverse modeling of the AFT lengths with the HeFTy computer program (Ketcham, 2005) according to the annealing model of Ketcham et al. (2007). Due to the high U content of its apatites (Fig. 9), sample 09-055 was the only one that showed enough horizontal confined tracks (54) for statistical validity. As discussed in Sect. 3.2, these apatite grains have a complex annealing behavior. Taking into account this complexity we performed several models, which all resulted in a consistent thermal history exemplified by the model shown in Fig. 10. The $t-T$ paths were forced to cross two fields (Fig. 10a): (i) from 20 to $26.6 \mathrm{Ma}$ (95\% CI from ZFT ages of the same sample) in the temperature window between 260 and $220^{\circ} \mathrm{C}$ as defined by the closing temperature of zircons (e.g., Reiners and Brandon, 2006); and (ii) from 7 to $3 \mathrm{Ma}$ between 30 and $0^{\circ} \mathrm{C}$ as defined by unconformable coal and lacustrine sediments (Steenbrink et al., 2006) containing gastropods (art Radix Auriculata, Fig. 7d) not older than Pliocene (Fig. 10c).

HeFTy calculated an AFT age of $19.5(+3.1-2.7)$ Ma and a mean track length of $12.59 \pm 2.33 \mu \mathrm{m}$ for sample $09-055$ (Fig. 10a and b). The best-fit model gave a goodness of fit index of 0.96 for the model age and 0.97 for the track lengths 


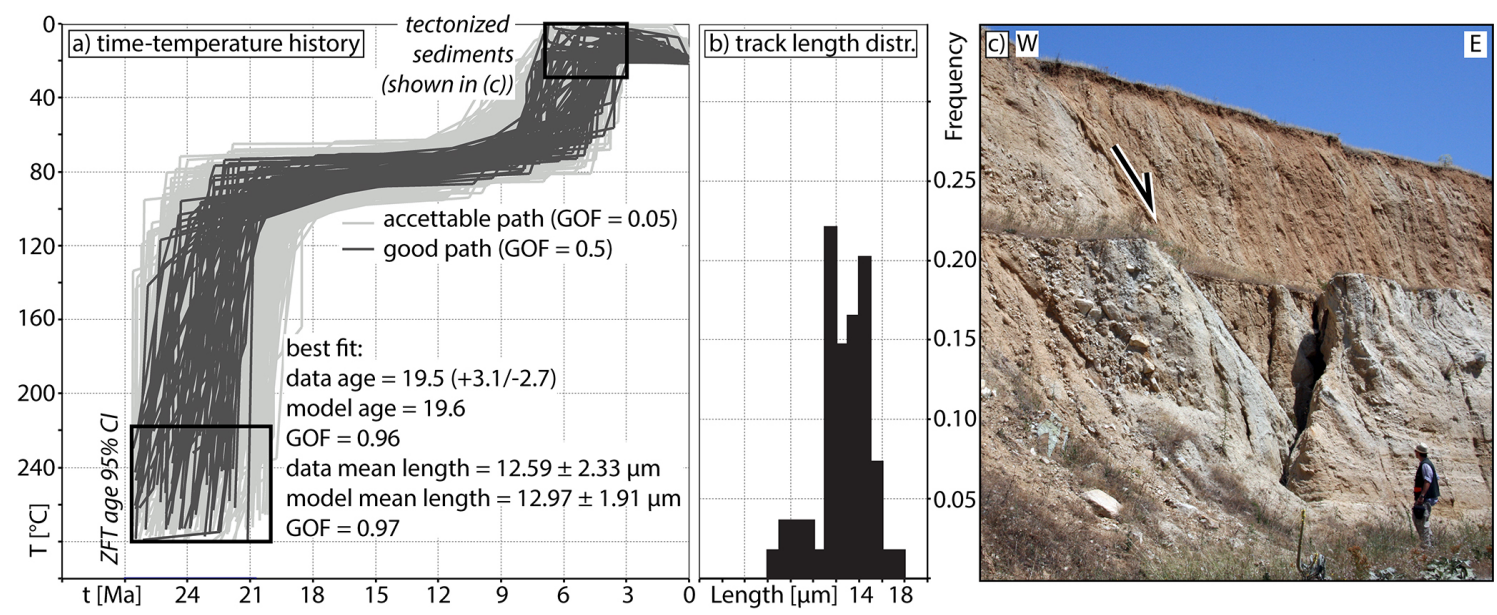

Figure 10. (a) $t-T$ paths of sample 09-055 modeled with computer program HeFTy (Ketcham, 2005). The "acceptable" (>0.05) and "good" (>0.5) goodness-of-fit indicate non-failure at 95 and $50 \%$ confidence interval, respectively. Inverse modeling is based on the simulation of 50000 random $t-T$ paths. (b) Distribution of counted horizontal track lengths. (c) Normal fault in deltaic-lacustrine sediments ( $<5 \mathrm{Ma})$ unconformably covering the Pelagonia crystalline rocks $\left(40^{\circ} 19^{\prime} 49.4^{\prime \prime} \mathrm{N}, 22^{\circ} 08^{\prime} 33.5^{\prime \prime} \mathrm{E}\right)$.

(Fig. 10a). The inverse modeling of the track lengths resulted in a three-step cooling history (Fig. 10a) from which we can roughly estimate cooling rates of (i) $20-40{ }^{\circ} \mathrm{C} \mathrm{Ma}^{-1}$ between 27 and $21 \mathrm{Ma}$, (ii) $1-3^{\circ} \mathrm{C} \mathrm{Ma}^{-1}$ from 21 to $7 \mathrm{Ma}$ and (iii) from below $80^{\circ} \mathrm{C}$ to surface temperatures in 2 to $4 \mathrm{Ma}$ between 7 to $3 \mathrm{Ma}$.

\section{Discussion}

\subsection{Detrital fission-track ages of the western AVAZ: 100-68 Ma post-collisional cooling and $68 \mathrm{Ma}$ abrupt and fast erosional denudation of Pelagonia}

In the studied area, the low-grade AVAZ imbricates (sample 10-029) have been covered unconformably by marine sediments from 93.5 to $90 \mathrm{Ma}$. The ZFT cooling age of these imbricates at $92.2 \mathrm{Ma}$ has a large uncertainty $(-9+10 \mathrm{Ma})$ that overlaps with the age of the sediments. As a consequence, cooling below ca. $240^{\circ} \mathrm{C}$ is placed between $102 \mathrm{Ma}$, which is the upper $68 \%$ CI of the ZFT age of sample 10-029, and 93 to $90 \mathrm{Ma}$, which is the age of the unconformable sediments.

The major thermotectonic event started $\sim 150 \mathrm{Ma}$ in the Rhodope and continued until $\sim 110 \mathrm{Ma}$ in Pelagonia (Fig. 2). According to Schenker et al. (2014), this protracted hightemperature event occurred during continental subduction and progressive collision during which deformation and metamorphism migrated from the Rhodope between 150 and $130 \mathrm{Ma}$ to the Pelagonia between 130 and $110 \mathrm{Ma}$. The AVAZ imbricates were not deeply subducted since they experienced low-grade metamorphic conditions only (sample 10029, Fig. 7a). After collision and before $66 \mathrm{Ma}$, marine conditions were installed over Pelagonia and the AVAZ, with an unconformity varying in space and time between the Ceno- manian and the Early Campanian (100 to $80 \mathrm{Ma}$ ). Deepening of the basin corresponds to a long history of residence at temperatures $<240{ }^{\circ} \mathrm{C}$ between 86 and ca. $68 \mathrm{Ma}$ in the northern Pelagonian, at $80 \mathrm{Ma}$ in the eastern AVAZ and at $72 \mathrm{Ma}$ in the western Rhodope (Fig. 1b). This period of slow cooling corresponds to tectonic quiescence, which suggests post-collisional cooling and thermal subsidence of the external orogenic pile throughout the Late Cretaceous (Fig. 11a).

The increase of coarse detritus at ca. $66 \mathrm{Ma}$ (Fig. 3) marks the end of the 20 to $30 \mathrm{Myr}-\mathrm{long}$ period of regional cooling and sedimentation. The ZFT age at $68(-6.1+5.6) \mathrm{Ma}$ (youngest detrital population of sample 10-130) and at 67.4 $(-4.8+5.2) \mathrm{Ma}$ (gneissic boulder of sample 10-128) overlaps the depositional age within error. The short lag time between cooling of the source rock and its erosion and deposition in the basin indicates fast denudation. The clastic sediments are very coarse, suggesting short transport distances and important mechanical erosion. The gneissic clasts and the rudist-bearing olistoliths constrain the sediment source to be in the now eroded southeastern Pelagonia, which had similar cooling ages as northern Pelagonia (Fig. 11b). Abrupt and rapid cooling at ca. $68 \mathrm{Ma}$ occurred during thrust migration that first buried the ca. $70 \mathrm{Ma}$ synorogenic mass flows of the AVAZ (Mercier and Vergely, 1994) and then the 40 to $38 \mathrm{Ma}$ External Hellenides (Brunn, 1956; Ferriére et al., 2004). Thrusting was accompanied by blueschist metamorphism dated between 61 and $42 \mathrm{Ma}$ with $\mathrm{Ar} / \mathrm{Ar}$ on white micas in southeastern Pelagonia (Fig. 11b, Schermer et al., 1990). During the thermal overprint and relaxation of this compressional event, western Pelagonia cooled below 240 and $110^{\circ} \mathrm{C}$ throughout the Eocene (Fig. $11 \mathrm{~b}$ and c). 
a) $86-68 \mathrm{Ma} \circ$
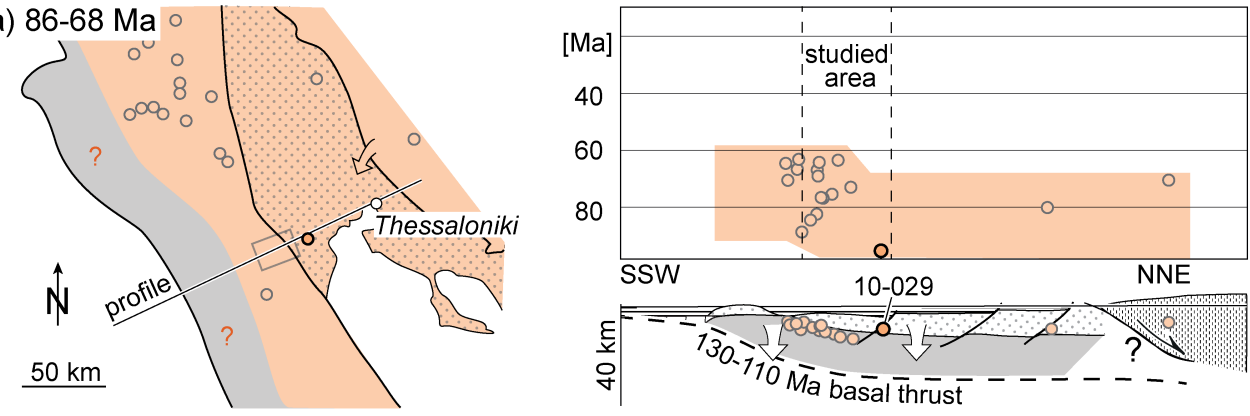

b) $68-40 \mathrm{Ma}$
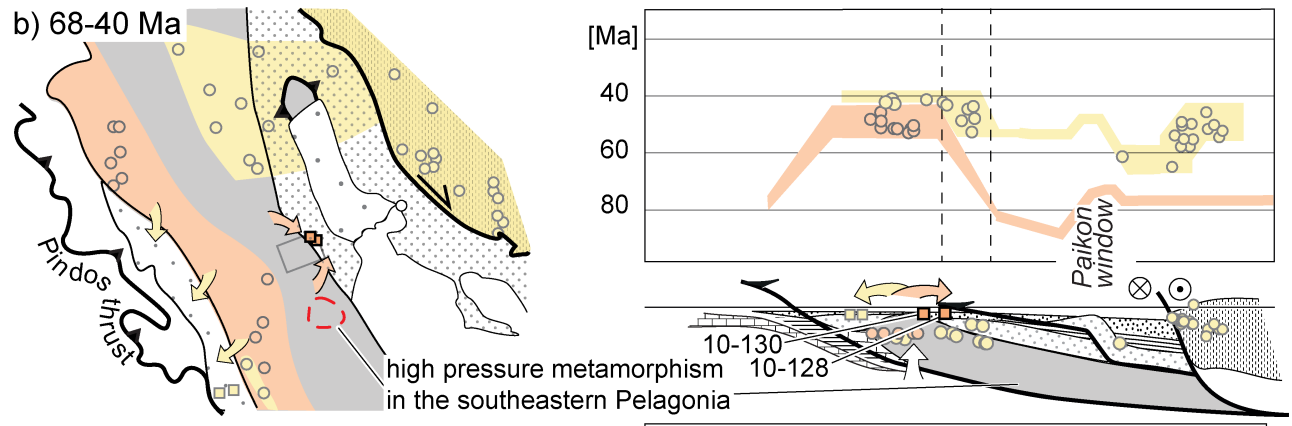

c) 4(
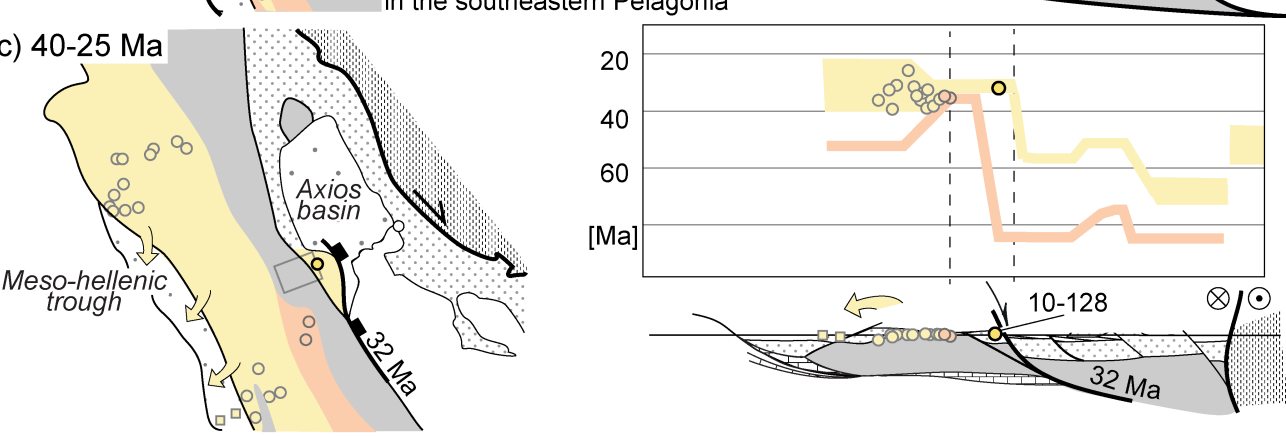

d) $25-16 \mathrm{Ma}$
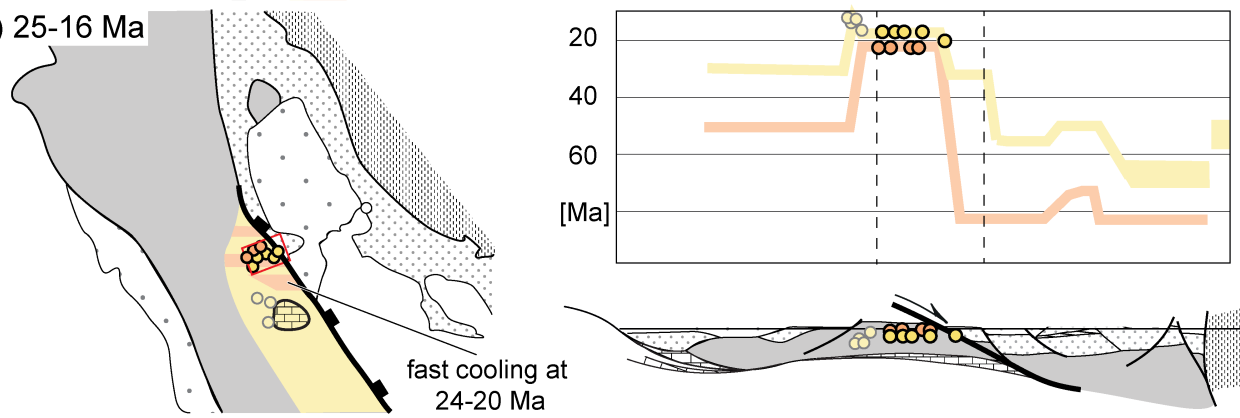

e) $16-0 \mathrm{Ma}$
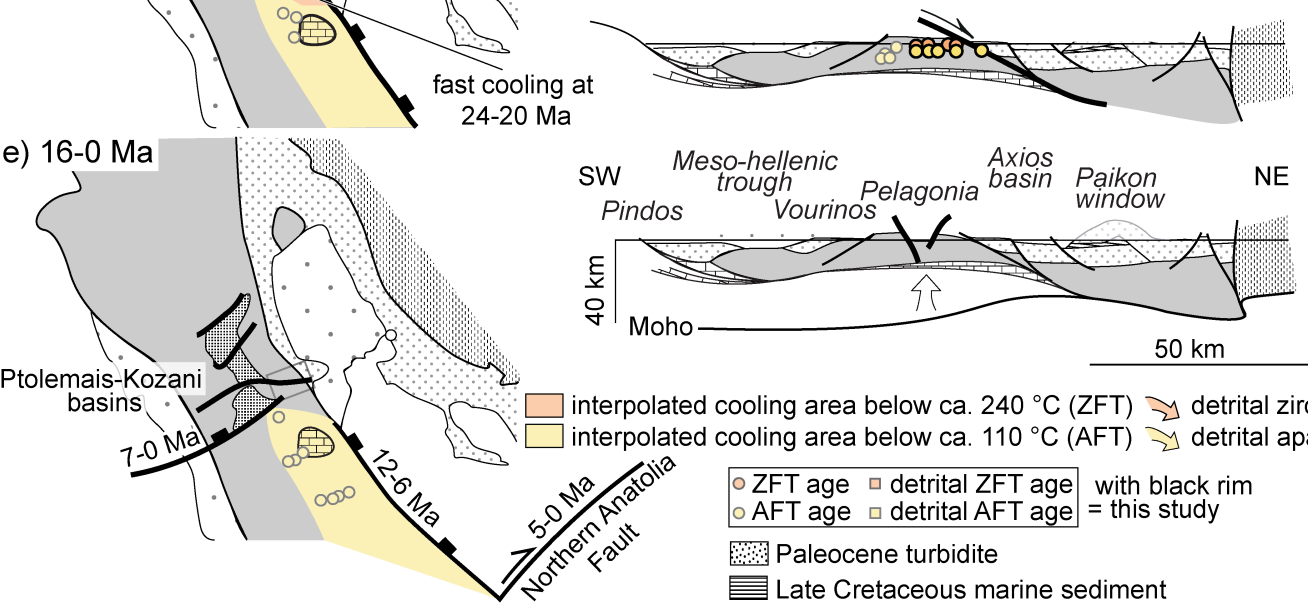

o-hellenic 


\subsection{Cooling and exhumation of the central-eastern Pelagonian gneiss: late Oligocene-to-Miocene extension}

New ZFT and AFT ages indicate Late Oligocene-Early Miocene cooling of the crystalline rocks of central-eastern Pelagonia. The small age difference between ZFT and AFT data (locally the $65 \%$ CI overlaps) and inverse modeling of the track lengths suggest fast and spatially uniform cooling from ca. 240 to ca. $80^{\circ} \mathrm{C}$ between 24 and $21 \mathrm{Ma}$. In the absence of a Late Oligocene-Early Miocene advected heat source (Schenker et al., 2014), this fast cooling hints at tectonic denudation along the reactivated top-to-the-ENE shear zone at the eastern margin of the Pelagonia (Figs. 5 and 11d). This normal shear zone now separates ca. 68 Ma detrital ZFT and $32.7 \mathrm{Ma}$ reset AFT ages in the hanging wall from 24 to $20.7 \mathrm{Ma}$ ZFT and 22.9 to $16.9 \mathrm{Ma}$ AFT ages in the footwall (Fig. 5). In the hanging wall, extensional tectonic slices incorporate Cretaceous sediments of sample 10-128, which cooled below $\sim 110^{\circ} \mathrm{C}$ at $32.7(-3.1+3.4 \mathrm{Ma})$. At this time, uplift and erosion of the western AVAZ is shown by the erosional unconformity of Miocene sediments on tilted Late Lutetian ( $\sim 41 \mathrm{Ma})$-to-Lower Oligocene $(\sim 30 \mathrm{Ma})$ marine sediments in the neighboring Axios basin (Roussos, 1994). This suggests that tectonic denudation in the western AVAZ started even earlier, at $\sim 33 \mathrm{Ma}$, during local extension in a regional transtensional regime (Ricou et al., 1998, Fig. 11c and d). Furthermore, cooling $\sim 80 \mathrm{~km}$ to the south in the footwall of the same normal fault zone started at 23 to $20 \mathrm{Ma}$ (Schermer et al., 1990; Lecassin et al., 2007) and peaked between 16 and $6 \mathrm{Ma}$ (Coutand et al., 2014). The difference in time of fast cooling along the same normal fault zone may be related to diachronous fault activity along strike (Fig. 11d and e).

Two mechanisms are envisaged for the 33 to $16 \mathrm{Ma}$ extension in central-eastern Pelagonia: (i) local extension above an antiformal stack duplex during continuous underthrusting of the External Hellenides (Ferrière et al., 2004) and (ii) distributed extension during southward rollback of the Hellenic slab (e.g., Le Pichon et al., 1979; Brun and Faccenna, 2008) after the Late Cretaceous-Eocene compression. At ca. $15 \mathrm{Ma}$ the trench of the Hellenic subduction was already migrating westward over $80 \mathrm{~km}$ and was located ca. $200 \mathrm{~km}$ from the central-eastern Pelagonia (Royden and Papanikolaou, 2011). Assuming a slab with low angle $\left(30^{\circ}\right)$ at this time, the slab interface was ca. $115 \mathrm{~km}$ below central-eastern Pelagonia. Because a $115 \mathrm{~km}$ thick duplex is mechanically unrealistic, we do not favor hypothesis (i). Therefore, the 33 to $16 \mathrm{Ma}$ cooling is the oldest and northeasternmost thermal expression of the southward rollback of the Hellenic slab.

\subsection{Pliocene cooling and uplift}

Late Miocene-Pliocene lacustrine sediments locally covered the studied area, attesting exposure of the Pelagonian gneiss after $7 \mathrm{Ma}$. These data have been used to constrain the inverse modeling of the FT lengths, which disclose rapid cooling after ca. $7 \mathrm{Ma}$ from the upper AFT partial retention zone at ca. $80^{\circ} \mathrm{C}$ to the surface. W-E to SW-NE trending normal faults cutting the lacustrine sediments demonstrate recent extension (Figs. 3, 4 and 10c). Footwalls of these faults raised the lacustrine sediments by more than $500 \mathrm{~m}$ higher than the hanging wall blocks and were carved by rivers in a concaveup shape typical for active surface uplift (Fig. 6). Therefore, the conspicuous relief in central Pelagonia evolved after $7 \mathrm{Ma}$ (Fig. 11e). These W-E to SW-NE trending faults have been interpreted as sinistral strike slips with horizontal displacement of ca. $20 \mathrm{~km}$ (van Hinsbergen and Schmid, 2012) because they are coeval and parallel to the sinistral North Anatolian fault (Fig. 11e). Nevertheless, our geological map and direct observations of fault striations contradict any significant strike slip movement (Fig. 4). Furthermore, the over $50 \mathrm{~km}$ distribution of normal faults shaping the intramontane basins of Kosani and Ptolemais (Fig. 11e) tangibly attests regional NW-SE extension rather than inferred, localized strike slip faulting.

\section{Conclusions}

The complex low-temperature history of the Pelagonian gneiss and the AVAZ preserved the record of a long residence at temperature below $240^{\circ} \mathrm{C}$ since $102 \mathrm{Ma}$. Thus, since that time, the Pelagonian tectonic units have not been involved in crustal-scale burial processes that would have produced elevated thermal conditions. In this upper-crustal tectonic context, the combined use of fission-track dating, structural and stratigraphic data were essential to unravel protracted cooling events as follows (Fig. 11):

a. Cooling below $240^{\circ} \mathrm{C}$ of the metamorphic western AVAZ imbricates between 102 and 93 to $90 \mathrm{Ma}$, of northern Pelagonia between 86 and $68 \mathrm{Ma}$, of the eastern AVAZ at $80 \mathrm{Ma}$ and of the western Rhodope at $72 \mathrm{Ma}$. This followed continental subduction and overall collision of Rhodope and Pelagonia with Eurasia; the tectonometamorphic overprint peaked at 150 to $130 \mathrm{Ma}$ in the internal zones (Rhodope) and at 130 to $110 \mathrm{Ma}$ in the external zones (Pelagonia). Therefore, the 40 to 20 a-long heterogeneous regional cooling, the contemporaneous deepening of the 100 to 68 Ma marine basins on the external zones (Pelagonia and AVAZ) and the regional tectonic quiescence suggest thermal subsidence after erosion of the Early Cretaceous orogeny (Fig. 11a).

b. Abrupt and rapid cooling below $240^{\circ} \mathrm{C}$ of the Pelagonian gneiss at about $68 \mathrm{Ma}$ due to erosional denudation during basal thrusting and crustal thickening. Its thermal effect lasted until ca. $40 \mathrm{Ma}$ according to ZFT and AFT in western and eastern Pelagonia, respectively (cf. Fig. 11b). 
c. Cooling below $120^{\circ} \mathrm{C}$ of the western $\mathrm{AVAZ}$ from $33 \mathrm{Ma}$ and between 240 and $80^{\circ} \mathrm{C}$ of the central-eastern Pelagonian from 24 to $16 \mathrm{Ma}$. These two zones cooled from different tectonic levels in the footwall of westward migrating normal faults with top-to-the-NE sense of shear (Figures 11c and d). Extension is attributed to rollback of the Hellenic slab. d. Post-7 Ma cooling below $80^{\circ} \mathrm{C}$ during Pliocene-torecent, normal faulting in central-eastern Pelagonia (Fig. 11e). 


\section{Appendix A: description of rudists in olistoliths of the Upper Cretaceous sedimentary sequence}

Lenticular or blocky olistoliths of recrystallized limestone contain rudist, oyster, corals and benthic foraminifera. Three rudists belong to a post-Cenomanian-to-Maastrichtian genus: (i) Durania (radiolitid), (ii) Radiolitidae and (iii) Plagioptychidae. Although none of these generic identifications can yet be considered secure without closer study, the rudists indicate independently the same lower stratigraphic bracket. This defines the existence of a carbonatic platform in the Mid-Late-Cretaceous.

\section{i. Durania (Radiolitid)}

A shell fragment shows a multilayered structure with a dark inner and a complex outer layer. This outer layer has a ca. $1 \mathrm{~cm}$ thick cellular structure in the internal part and a $3 \mathrm{~mm}$ thick lenticular structure in the external part (Fig. A1a in Appendix). The outer lenticular structures are the expression, in transverse section, of fine regular riblets on the surface of the shell, in this case adjoining those from a superficial fragment of another shell, which probably was attached to it. The cellular texture of the outer layer and the regular fine external riblets characterize a fragment of Durania (Radiolitid) (e.g., Cobban et al., 1991). In order to confirm this generic identification, however, we would need to observe the absence of a ligamentary infolding on the dorsal inner margin of the outer shell layer, as well as distinct radial bands with finer ribbing on its external posteroventral flank; unfortunately, none of these parts of the shell are visible in this fragment. The most abundant occurrence of Durania is from the Late Albian to the Maastrichtian, even without a regular outer layer (like the shell in Fig. A1a), which is not typical for the Late Cretaceous genus. This specimen is probably not older than Cenomanian (e.g., Cobban et al., 1991).

\section{ii. Radiolitidae}

The shell consist of an internal thin layer and an external polygonal mesh, representing a traverse section through a rudist valve (Fig. A1b). The regular polygonal (mostly hexagonal) shell ornament of the outer layer is characteristic for rudists of the family Radiolitidae. The first representative, with a poorly developed cellular layer, is Albian (Fenerci-Masse et al., 2006). The more prominent celluloprismatic outer layer (as in Fig. A1b) is typically well developed in the Cenomanian to Maastrichtian forms (e.g., Fenerci-Masse et al., 2006).

\section{iii. Plagioptychidae}

The outer valve layer displays radial lines that are interpreted as pallial canals separated by tightly bifurcating laminae. Valve inwards, there is a $1 \mathrm{~mm}$ white calcitic layer with no discernible internal textures, followed by a $3 \mathrm{~mm}$ grey layer and a $2 \mathrm{~mm}$ lighter layer with no discernible internal textures (Fig. A1c and d). The grey layer is probably constituted by detrital components, hinting to cavity fill in the inner-valve layer (the latter consists of the two calcitic layers with no internal structure). The form of the canals and the cavity in the internal layer are typical of the left valve of Plagioptychidae (Fig. 7 of Skelton, 2013). The plagioptychids range from the Late Turonian to the Maastrichtian (e.g., Skelton, 2013). 

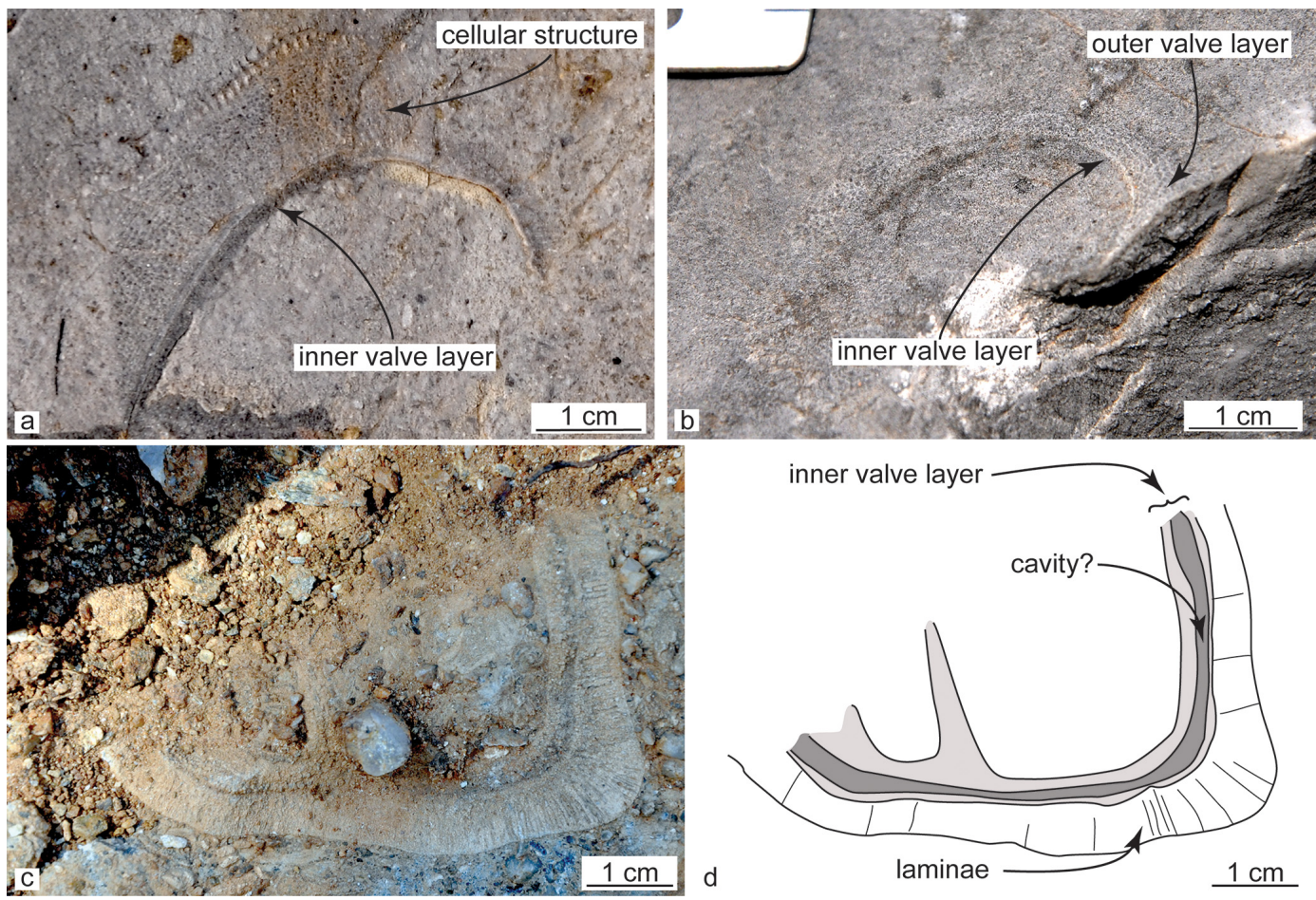

Figure A1. (a) Composite shell of a rudist (Durania) $\left(40^{\circ} 27^{\prime} 40.7^{\prime \prime} \mathrm{N}, 22^{\circ} 13^{\prime} 13.8^{\prime \prime} \mathrm{E}\right)$; (b) bi-layered shell of the Radiolitidae showing an external layer with polygonal ornaments $\left(40^{\circ} 27^{\prime} 31.2^{\prime \prime} \mathrm{N}, 22^{\circ} 13^{\prime} 07.7^{\prime \prime} \mathrm{E}\right)$; (c) multilayer architecture of a rudist shell fragment (Plagioptychid) in a conglomerate, showing radial laminae in the outer-valve layer $\left(40^{\circ} 27^{\prime} 45.1^{\prime \prime} \mathrm{N}, 22^{\circ} 12^{\prime} 26.7^{\prime \prime} \mathrm{E}\right)$; (d) sketch of the rudist fragment shown in (c). 
Acknowledgements. This work was supported by ETH research grant ETH-09 09-3. We are grateful to M. Zattin, D. Bernoulli and an anonymous referee for the contributions and comments that helped to improve this paper. We thank the following colleagues for help with fossil identification: P. Hochueli (gastropod), D. Bernoulli and S. Spezzaferri (foraminifera), P. Skelton and I. Stössel (rudists). Discussions with E. Moulas and P. Baumgartner helped clarify correlations.

Edited by: F. Rossetti

\section{References}

Anders, B., Reischmann, T., and Kostopoulos, D.: Zircon geochronology of basement rocks from the Pelagonian Zone, Greece: constraints on the pre-Alpine evolution of the westernmost Internal Hellenides, Internat. J. Earth Sci., 96, 639-661, 2007.

Aubouin, J.: Des tectoniques superposées et de leur signification par rapport aux modèles géophysiques: l'example des Dinarides; paléotectonique, tectonique, tarditectonique, néotectonique Bull. Soc. Géol. Fr., 7, 428-460, 1973.

Baumgartner, P. O.: Jurassic sedimentary evolution and nappe emplacement in the Argolis Peninsula (Peloponnesus; Greece), Mém. Soc. Helv. Sci. Nat., 99, 1-111, 1985.

Bernoulli, D. and Laubscher, H.: The palinspastic problem of the Hellenides, Ecl. Geol. Helvet., 65, 1007-1118, 1972.

Bortolotti, V., Carras, N., Chiari, M., Fazzuoli, M., Marcucci, M., Photiades, A., and Principi, G.: The Argolis Peninsula in the palaeogeographic and geodynamic frame of the Hellenides, Ofioliti, 28, 79-94, 2003.

Bortolotti, V., Chiari, M., Marcucci, M., Photiades, A., Principi, G., and Saccani, E.: New geochemical and age data on the ophiolites from the Othrys area (Greece): implication for the Triassic evolution of the Vardar ocean, Ofioliti, 33, 135-151, 2008.

Bolli, H.: Zur Stratigraphie der Oberen Kreide in den höheren helvetischen Decken, Ecl. Geol. Helvet., 37, p. 226, 1945.

Bonneau, M., Godfriaux, I., Moulas, Y., Fourcade, E., and Masse, J.: Stratigraphie et structure de la bordure orientale de la double Fenêtre du Païkon (Macédoine, Grèce), Bull. Geol. Soc. Greece XXX, 105-114, 1994.

Brandon, M. T.: Probability density plot for fission-track grain-age samples, Radiat Meas, 26, 663-676, 1996.

Brun, J. P. and Faccenna, C.: Exhumation of high-pressure rocks driven by slab rollback, Earth Planet Sc. Lett., 272, 1-7, 2008.

Brunn, J.: Contribution à l'étude Géologique du Pinde septentrional et d'une partie de la Macédoine Occidentale, Ann. Geol. Pays. Hellen., 7, 1-358, 1956.

Burg, J.-P.: Rhodope: From Mesozoic convergence to Cenozoic extension. Review of petro-structural data in the geochronological frame, J. Virt. Expl., 42, 1-44, 2012.

Burtner, R. L., Nigrini, A., and Donelick, R. A.: Thermochronology of Lower Cretaceous Source Rocks in the Idaho-Wyoming Thrust Belt, Aapg Bull.-Am. Associat. Petrol. Geol., 78, 16131636, 1994.

Carlson, W. D., Donelick, R. A., and Ketcham, R. A.: Variability of apatite fission-track annealing kinetics: I. Experimental results, Am. Mineral., 84, 1213-1223, 1999.
Chiari, M., Baumgartner, P. O., Bernoulli, D., Bertolotti, V., Marcucci, M., Phodiades, A., and Principi, G.: Late Triassic, Early and Middle Jurassic Radiolaria from ferromanganese-chert "nodules" (Angelokastron, Argolis, Greece): evidence for prolonged radiolarite sedimentation in the Maliac-Vardar Ocean, Facies, 2012.

Clift, P. and Dixon, J.: Jurassic ridge collapse, subduction initiation and ophiolite obduction in the southern Greek Tethys, Ecl. Geol. Helvet., 91, 123-138, 1998.

Cobban, W., Skelton, P., and Kennedy, W.: Occurrence of the rudistid Durania cornupastoris (Des Moulins, 1826) in the Upper Cretaceous Greenhorn Limestone in Colorado, US Geol. Surv. Bull. for 1985, D1-D8, 1991.

Coutand, I., Walsh, M., Louis, B., Chanier, F., Ferriére, J., and Reynaud, J.-Y.: Neogene upper-crustal cooling of the Olympus range (northern Aegean): Major role of Hellenic back-arc extension over propagation of the North Anatolia Fault Zone, Terra Nova, 287-297, 2014.

Fenerci-Masse, M., Masse, J. P., Arias, C., and Vilas, L.: Archaeoradiolites, a new genus from the Upper Aptian of the Mediterranean region and the origin of the rudist family Radiolitidae, Palaeontology, 49, 769-794, 2006.

Ferrière, J., Reynaud, J.-Y., Pavlopoulos, A., Bonneau, M., Migiros, G., Chanier, F., Proust, J.-N., and Gardin, S.: Geologic evolution and geodynamic controls of the Tertiary intramontane piggyback Meso-Hellenic basin, Greece. Bull. Soc. géol. Fr., 175, 361-381, 2004.

Galbraith, R. F.: On statistical models for fission track counts, Mathemat. Geol., 13, 471-477, 1981.

Gawlick, H. J., Frisch, W., Hoxha, L., Dumitrica, P., Krystyn, L., Lein, R., Missoni, S., and Schlagintweit, F.: Mirdita Zone ophiolites and associated sediments in Albania reveal Neotethys Ocean origin, Internat. J. Earth Sci., 97, 865-881, 2008.

Godfriaux, I., Ferrière, J., and Schmitt, A.: Le développement en contexte continental d'un métamorphisme HP/BT: les "schistes bleus" tertiaires Thessaliens, Bull. Geol. Soc. Greece XX, 175192, 1988.

Hurford, A. J.: International-Union-of-Geological-Sciences Subcommission on Geochronology Recommendation for the Standardization of Fission-Track Dating Calibration and Data Reporting, Nuclear Tracks Radiat. Measurem., 17, 233-236, 1990.

IGME: Kolindros sheet, Geological map of Greece 1 : 50 000, Institute of geology and mineral exploration, Greece, 1991.

Ivanova, D., Bonev, N., and Chatalov, A.: Biostratigraphy and tectonic significance of lowermost Cretaceous carbonate rocks of the Circum-Rhodope Belt (Chalkidhiki Peninsula and Thrace region, NE Greece), Cretaceous Res., 52, 25-63, 2015.

Jacobshagen, V., Dürr, S., Kockel, F., Kopp, K.O., Kowalczyk, G., Berckhemer, H., and Büttner, D.: Structure and geodynamic evolution of the Aegean region, in: Alps, Appenines, Hellenides, edited by: Cloos, H., Roeder, D., and Schmidt, K., E. Schweizerbart'sche Verlagsbuchhandlung, Stuttgart, 537-564, 1978.

Jones, G. and Robertson, A. H.: Tectono-stratigraphy and evolution of the Mesozoic Pindos ophiolite and related units, northwestern Greece, J. Geol. Soc., 148, 267-288, 1991.

Ketcham, R. A.: Forward and Inverse Modeling of LowTemperature Thermochronometry Data, Rev. Mineral. Geochem., 58, 275-314, 2005. 
Ketcham, R. A., Carter, A., Donelick, R. A., Barbarand, J., and Hurford, A. J.: Improved modeling of fission-track annealing in apatite, Am. Mineral., 92, 799-810, 2007.

Kilias, A., Frisch, W., Avgerinas, A., Dunkl, I., Falalakis, G., and Gawlick, H. J.: Alpine architecture and kinematics of deformation of the northern Pelagonian nappe pile in the Hellenides, Austr. J. Earth Sci., 103, 4-28, 2010.

Koukouzas, C. N., Kotis, T., Ploumidis, M., and Metaxas, A.: Coal exploration of Anargiri area, Amynteon (W. Macedonia). Mineral Deposit Research, Natl. Institute Geol. Mining Res., 5-14, 22-34, 1979.

Kounov, A., Wüthrich, E., Seward, D., Burg, J.-P., and Stockli, D.: Low-temperature constraints on the Cenozoic thermal evolution of the Southern Rhodope Core Complex (Northern Greece), Internat. J. Earth Sci., 2015.

Kydonakis, K., Gallagher, K., Brun, J. P., Jolivet, M., Gueydan, F., and Kostopoulos, D.: Upper Cretaceous exhumation of the western Rhodope Metamorphic Province (Chalkidiki Peninsula, northern Greece), Tectonics, 33, 1113-1132, 2014.

Le Pichon, X., Angelier, J., Aubouin, J., Lyberis, N., Monti, S., Renard, V., Got, H., Hsu, K., Mart, Y., Mascle, J., Matthews, D., Mitropoulos, D., Tsoflias, P., and Chronis, G.: From Subduction to Transform Motion - Seabeam Survey of the Hellenic Trench System, Earth Planet Sc. Lett., 44, 441-450, 1979.

Lecassin, R., Arnaud, N., Leloup, P. H., Armijo, R., and Meyer, B.: Syn- and post-orogenic exhumation of metamorphic rocks in North Aegean, eEarth, 2, 51-63, 2007.

Lips, A. L. W., White, S. H., and Wijbrans, J. R.: ${ }^{40} \mathrm{Ar} /{ }^{39} \mathrm{Ar}$ laserprobe direct dating of discrete deformational events: a continuous record of early Alpine tectonics in the Pelagonian Zone, NW Aegean area, Greece, Tectonophysics, 298, 133-153, 1998.

Lock, J. and Willett, S.: Low-temperature thermochronometric ages in fold-and-thrust belts, Tectonophysics, 456, 147-162, 2008.

Mavridou, E., Antoniadis, P., Khanaqa, P., Riegel, W., and Gentzis, T.: Paleoenvironmental interpretation of the AmynteonPtolemaida lignite deposit in northern Greece based on its petrographic composition, Internat. J. Coal Geol., 56, 253-268, 2003.

Mercier, J. and Vergély, P.: Is the Païkon Massif a tectonic window in the Axios-Vardar zone? (Internal Hellenides, Macedonia, Greece), Bullet. Geol. Soc. Greece XXX/1, 115-120, 1994.

Most, T.: Geodynamic evolution of the Eastern Pelagonia zone in the Northwestern Greece and the Republic of Macedonia Geowissenschaftlichen Fakultät, Eberhardt-Karls-Universität Tübingen, Tübingen, p. 195, 2003.

Most, T., Frisch, W., Dunkl, I., Kadosa, B., Boev, B., Avgerinas, A., and Kilias, A.: Geochronological and structural investigations of the northern Pelagonian crystalline zone - Constraints from K/Ar and zircon and apatite fission track dating, Geol. Soc. Greece Bullet., 34, 91-95, 2001.

Naeser, C. W.: Fission-Track Dating, US Geological Survey Open File Report, 76-190, 1976.

Papanikolaou, D.: The tectonostratigraphic terranes of the Hellenides, Annales Géologiques des Pays Helléniques 37, 495-514, 1997.

Papanikolaou, D.: Timing of tectonic emplacement of the ophiolites and terrane paleogeography in the Hellenides, Lithos, 108, 262 280, 2009.

Pavlides, S. B., Zouros, N. C., Chatzipetros, A. A., Kostopoulos, D. S., and Mountrakis, D. M.: The 13 May 1995 Western Macedo- nia, Greece (Kozani-Grevena) earthquake - preliminary-results, Terra Nova, 7, 544-549, 1995.

Reiners, P. W. and Brandon, M. T.: Using thermochronology to understand orogenic erosion, Ann. Rev. Earth Planet. Sci., 34, 419466, 2006

Renz, C. and Reichel, M.: Beiträge zur Stratigraphie und Paläontologie des Ostmediterranen Jungpaläozoikums und dessen Einordnung im griechischen Gebirgsystem, Ecl. Geol. Helvet., 38, 221-313, 1945.

Ricou, L. E., Burg, J. P., Godfriaux, I., and Ivanov, Z.: Rhodope and Vardar: the metamorphic and the olistostromic paired belts related to the Cretaceous subduction under Europe, Geodinam. Ac., 11, 285-309, 1998.

Roussos, N.: Stratigraphy and paleogeographic evolution of the $\mathrm{Pa}-$ leogene Molassic basins of the North Aegean area, Bulle. Geol Soc. Greece, 30, 275-294, 1994.

Royden, L. H. and Papanikolaou, D. J.: Slab segmentation and late Cenozoic disruption of the Hellenic arc, Geochem. Geophy. Geosy., 1-24, 2011.

Schenker, F. L., Burg, J.-P., Kostopoulos, D., Moulas, E., Larionov, A., and von Quadt, A.: From Mesoproterozoic magmatism to collisional Cretaceous anatexis: Tectonomagmatic history of the Pelagonian Zone, Greece, Tectonics, 2014TC003563, 2014.

Schermer, E. R., Lux, D. R., and Burchfiel, B. C.: Temperature-time history of subducted continental-crust, Mount Olympos region, Greece, Tectonics, 9, 1165-1195, 1990.

Schermer, E. R.: Geometry and kinematics of continental basement deformation during the Alpine orogeny, Mt. Olympus region, Greece, J. Struct. Geol., 15, 571-591, 1993.

Schmid, S. M., Bernoulli, D., Fugenschuh, B., Matenco, L., Schefer, S., Schuster, R., Tischler, M., and Ustaszewski, K.: The AlpineCarpathian-Dinaridic orogenic system: correlation and evolution of tectonic units, Swiss J. Geosci., 101, 139-183, 2008.

Sharp, I. R. and Robertson, A. H. F.: Tectonicsedimentary evolution of the western margin of the Mesozoic Vardar Ocean: evidence from the Pelagonian and Almopias zones, northern Greece, in: Tectonic Development of the Eastern Mediterranean Region, edited by: Robertson, A. H. F. and Mountrakis, D., Geol. Soc., London, 373-412, 2006.

Skelton, P. W.: Rudist classification for the revised Bivalvia volumes of the "Treatise on Invertebrate Paleontology", Caribb. J. Earth Sci., 45, 9-33, 2013.

Smith, A. and Rassios, A.: The evolution of ideas for the origin and emplacement of the western Hellenic ophiolites, Special PapersGeol. Soc. Am., 337-35, 2003.

Smith, A., Woodcock, N., and Naylor, M.: The structural evolution of a Mesozoic continental margin, Othris Mountains, Greece, J. Geol. Soc., 136, 589-601, 1979.

Spear, F. S.: Metamorphic Phase Equilibria and PressureTemperature-Time Paths, Washington, DC, 1995.

Steenbrink, J., Hilgen, F. J., Krijgsman, W., Wijbrans, J. R., and Meulenkamp, J. E.: Late Miocene to Early Pliocene depositional history of the intramontane Florina-Ptolemais-Servia Basin, NW Greece: Interplay between orbital forcing and tectonics, Palaeogeogr. Palaeocl., 238, 151-178, 2006.

Vamvaka, A., Spiegel, C., Frisch, W., Danisik, M., and Kilias, A.: Fission track data from the Mesohellenic Trough and the Pelagonian zone in NW Greece: Cenozoic tectonics and exhumation of source areas, Internat. Geol. Rev., 52, 223-248, 2010. 
van Hinsbergen, D. J. J. and Schmid, S. M.: Map view restoration of Aegean-West Anatolian accretion and extension since the Eocene, Tectonics, 1-40, 2012.

Viquesnel, A.: Résumé des observations géographiques et géologiques faites, en 1847, dans la Turquie d'Europe, Bull. Soc. Géol. Fr., 2, 454-475, 1853.
Wüthrich, E. D.: Low temperature thermochronology of the northern Aegean Rhodope Massif, Earth Sciences, Swiss Federal Institute of technology Zurich, Zurich, p. 210, 2009.

Yarwood, G. A. and Dixon, J. E.: Lower Cretaceous and younger thrusting in the Pelagonian rocks of High Piera, Greece, 6th Colloq, Aegean Region, Athens, 1, 269-280, 1977. 